Review

\title{
Type 1 Diabetes Mellitus in the SARS-CoV-2 Pandemic: Oxidative Stress as a Major Pathophysiological Mechanism Linked to Adverse Clinical Outcomes
}

\author{
Aikaterini Kountouri ${ }^{1}$ (D) Emmanouil Korakas ${ }^{1}$ (D), Ignatios Ikonomidis ${ }^{2} \mathbb{D}$, Athanasios Raptis ${ }^{1}$, \\ Nikolaos Tentolouris ${ }^{3}$ (D) , George Dimitriadis ${ }^{4,+} \mathbb{D}$ and Vaia Lambadiari ${ }^{1, *,+}$
}

check for

updates

Citation: Kountouri, A.; Korakas, E.; Ikonomidis, I.; Raptis, A.; Tentolouris, N.; Dimitriadis, G.; Lambadiari, V. Type 1 Diabetes Mellitus in the SARS-CoV-2 Pandemic: Oxidative Stress as a Major Pathophysiological Mechanism Linked to Adverse Clinical Outcomes. Antioxidants 2021, 10,752. https://doi.org/10.3390/ antiox10050752

Academic Editors: Javier Diaz-Castro, Jorge Moreno-Fernandez and Julio Ochoa Herrera

Received: 29 March 2021

Accepted: 3 May 2021

Published: 9 May 2021

Publisher's Note: MDPI stays neutral with regard to jurisdictional claims in published maps and institutional affiliations.

Copyright: (c) 2021 by the authors. Licensee MDPI, Basel, Switzerland. This article is an open access article distributed under the terms and conditions of the Creative Commons Attribution (CC BY) license (https:/ / creativecommons.org/licenses/by/ $4.0 /)$.
1 Second Department of Internal Medicine, Attikon University Hospital, Medical School, National and Kapodistrian University of Athens, 12462 Athens, Greece; KaterinaK90@hotmail.com (A.K.); mankor-th@hotmail.com (E.K.); atraptis@med.uoa.gr (A.R.)

2 Second Cardiology Department, Attikon University Hospital, Medical School, National and Kapodistrian University of Athens, 12462 Athens, Greece; ignoik@gmail.com

3 First Department of Propaedeutic and Internal Medicine, Medical School, National and Kapodistrian University of Athens, Laiko General Hospital, 11527 Athens, Greece; ntentolouris@yahoo.gr

4 Sector of Medicine, Medical School, National and Kapodistrian University of Athens, 11527 Athens, Greece; gdimitr@med.uoa.gr

* Correspondence: vlambad@otenet.gr

$\dagger$ Equal contribution.

Abstract: Recent reports have demonstrated the association between type 1 diabetes mellitus (T1DM) and increased morbidity and mortality rates during coronavirus disease (COVID-19) infection, setting a priority of these patients for vaccination. Impaired innate and adaptive immunity observed in T1DM seem to play a major role. Severe, life-threatening COVID-19 disease is characterized by the excessive release of pro-inflammatory cytokines, known as a "cytokine storm". Patients with T1DM present elevated levels of cytokines including interleukin-1a (IL), IL-1 $\beta$, IL-2, IL-6 and tumor necrosis factor alpha (TNF- $\alpha$ ), suggesting the pre-existence of chronic inflammation, which, in turn, has been considered the major risk factor of adverse COVID-19 outcomes in many cohorts. Even more importantly, oxidative stress is a key player in COVID-19 pathogenesis and determines disease severity. It is well-known that extreme glucose excursions, the prominent feature of T1DM, are a potent mediator of oxidative stress through several pathways including the activation of protein kinase $\mathrm{C}(\mathrm{PKC})$ and the increased production of advanced glycation end products (AGEs). Additionally, chronic endothelial dysfunction and the hypercoagulant state observed in T1DM, in combination with the direct damage of endothelial cells by severe acute respiratory syndrome coronavirus 2 (SARS-CoV-2), may result in endothelial and microcirculation impairment, which contribute to the pathogenesis of acute respiratory syndrome and multi-organ failure. The binding of SARS-CoV-2 to angiotensin converting enzyme 2 (ACE2) receptors in pancreatic b-cells permits the direct destruction of b-cells, which contributes to the development of new-onset diabetes and the induction of diabetic ketoacidosis (DKA) in patients with T1DM. Large clinical studies are required to clarify the exact pathways through which T1DM results in worse COVID-19 outcomes.

Keywords: inflammation; immunity; oxidative stress; SARS-CoV-2; type 1 diabetes mellitus; hyperglycemia; endothelial dysfunction; ACE2

\section{Introduction}

Coronavirus disease (COVID-19) is a newly recognized infection that was first reported in Wuhan, China in December 2019 and has rapidly spread worldwide. COVID-19 is caused by a novel enveloped RNA beta-coronavirus named severe acute respiratory syndrome coronavirus 2 (SARS-CoV-2) [1,2]. On 11 March 2020, the World Health Organization (WHO) declared the outbreak of COVID-19 as a pandemic after recording 118,000 cases 
globally in 114 different countries [3]. The clinical presentation of COVID-19 infection ranges from no or mild symptoms to critical illness including multi-organ failure and even death $[4,5]$. The mortality and morbidity rates of COVID-19 infection are increased in patients with underlying comorbidities [6]. Several epidemiological studies have pointed out that the percentage of underlying comorbidities such as diabetes, hypertension and cardiovascular diseases was significantly higher in COVID-19 patients requiring hospitalization in a medicine or intensive care unit [7-9]. Regarding diabetes in particular, the Center for Disease Control and Prevention reports that patients with diabetes are more prone to severe illness and to poorer clinical outcomes [10].

In the literature there are several reports regarding the prevalence, the clinical outcomes, and the pathophysiological mechanisms of COVID-19 in patients with type 2 diabetes mellitus (T2DM) [11-13]. However, research data concerning the effect of SARS-CoV-2 on patients with type 1 diabetes mellitus (T1DM) are scarce [14]. A multicenter study from the United Kingdom was the first that investigated the characteristics and clinical outcomes of COVID-19 infection in patients with T1DM, reporting that severity and mortality risk are also higher in T1DM. Furthermore, research data demonstrated that hyperglycemia is the most prevalent presenting symptom of COVID-19 disease, and diabetic ketoacidosis (DKA) is the most frequent adverse outcome in patients with preexisting T1DM [15]. Inversely, the preceding hyperglycemia in patients with T1DM is significantly associated with COVID-19-related mortality [16]. Interestingly, ambient hyperglycemia has been reported as an independent predictor for mortality and morbidity in patients with severe acute respiratory syndrome [17]. Moreover, SARS-CoV-2 has been suggested as a potential inducer of new-onset T1DM [18]. Based on the aforementioned research data, several potential factors and pathophysiological mechanisms, alone or in combination, may increase the susceptibility of subjects with T1DM to serious illness following COVID-19 infection. However, data about these mechanisms are scarce. The aim of the review is to describe the possible pathophysiological pathways that are associated with worse COVID-19 outcomes specifically in patients with T1DM.

\section{Material and Methods}

The studies mentioned in this review were retrieved by a computer search program using the PubMed, Scopus and Web of Science electronic databases. The authors searched for scientific literature published in English up to February 2021. The applied search terms were a combination of the following: "coronavirus", "COVID-19", "SARS-CoV2", "ACE2", "type 1 diabetes mellitus", “hyperglycemia", "endothelium", "inflammation", "oxidative stress", "coagulopathy" and "immunity". Additional references were identified from reviewing the references cited in the original articles. The final reference list was generated on the basis of relevance to the topics covered in this publication, with the aim of covering multiple aspects of the association between T1DM and COVID-19, and describing possible pathophysiological mechanisms leading to adverse clinical outcomes in patients with T1DM during COVID-19 infection.

\section{T1DM and COVID-19 Disease: Epidemiological Data}

Diabetes—especially when poorly controlled — has been recognized as a strong and independent predictor of severe outcomes including death during COVID-19 infection [19-23]. In a systematic review of the literature, Apicella et al. [24] summarized the potential risk factors that could lead to worst outcomes in COVID-19-positive subjects with diabetes: hyperglycemia, older age, male sex, non-white ethnic groups, poor socioeconomic status, comorbidities (such as hypertension, cardiovascular/cerebrovascular disease, chronic kidney disease), obesity, inflammation, and coagulation [24]. However, although it can be assumed that most of the patients reported in the literature with severe outcomes from SARS-CoV2 had type 2 diabetes (T2DM), the information concerning type 1 diabetes (T1DM) is still scarce. 
The risk for severe COVID-19 disease in patients with T1DM has been investigated in the following studies: (a) Ebekozien et al. [15] reported clinical outcomes in 33 COVID19-positive subjects with T1DM-mean age was 24.8 years, median $\mathrm{HbA} 1 \mathrm{c}$ was $8.5 \%$, obesity/hypertension/cardiovascular disease were the most prevalent comorbidities and diabetic ketoacidosis the most prevalent adverse outcome (45.5\% of the cases). (b) Two reports by Barron et al. [25] and Holman et al. [14] from NHS UK covering almost all the general practices in England were the first to compare the risk for severe outcomes between T1DM and T2DM during COVID-19 infection addressing all the potential risk factors, including previous glycemic control. The results (adjusted for confounding factors) demonstrated that $1 / 3$ of all in-hospital deaths with COVID-19 occurred in people with diabetes; the overall risk was 3.5 times higher in those with T1DM, while people with T2DM were at about twice the risk, compared to people without a known diagnosis of diabetes. In people with T1DM, preceding hyperglycemia was significantly associated with COVID-19-related mortality at values of $\mathrm{HbA} 1 \mathrm{c}>10 \%$, whereas in those with $\mathrm{T} 2 \mathrm{DM}$ this risk was significant at $\mathrm{HbA} 1 \mathrm{c}$ of $7.6 \%$ or higher. Obesity (body mass index (BMI) $>30 \mathrm{~kg} / \mathrm{m}^{2}$ ) was almost equally associated with COVID-19-related deaths in both diabetes types. Old age ( $>70$ years), male sex, impaired renal function, previous cardiovascular comorbidities, deprived people in under-privileged communities and people of black ethnicity were also significantly associated with the highest risk of in-hospital death from COVID-19. These results are supported by a previous study in over 100,000 primary care adult patients with diabetes in England: those with T1DM and T2DM had 2-3-fold higher rates of all infections (including pneumonia, sepsis, and endocarditis) compared to patients without diabetes. A comparison of T1DM and T2DM revealed that the risk of hospitalization and infection-related death in the former versus the latter was 2-fold and 4-fold higher, respectively; older age ( $\geq 70$ years), morbid obesity $\left(B M I>40 \mathrm{~kg} / \mathrm{m}^{2}\right.$ ), serious comorbidities (cardiovascular disease, hypertension, chronic kidney failure) and residence in more deprived areas markedly increased the risk for severe infections and adverse outcomes, whereas the duration of diabetes seemed to play a role only in patients with T2DM [26]. (c) McGurnaghan et al. [27] investigated the risk factors for severe outcomes in COVID-19-infected subjects with T1DM and T2DM in the total population of Scotland. The authors showed that subjects with diabetes had $\sim 40 \%$ greater risk of developing fatal or critical care unit-treated COVID-19 disease compared to people without diabetes after adjustment for age and sex; the risk was 1.75 times higher in T1DM than in T2DM. Male sex, residence in deprived areas, comorbidities (retinopathy, chronic kidney disease), longer diabetes duration, worse glycemic control and previous hospitalization for hypoglycemia or ketoacidosis in the past five years were among the most prevalent risk factors. Adjustment for age, sex and diabetes duration revealed that people with T1DM and T2DM had a similar risk for COVID-19-related severe outcomes [27]. (d) In a prospective cohort study, Gregory et al. [28] identified 40 COVID-19positive patients with T1DM across a regional healthcare network of 137 service locations using electronic health records at Vanderbilt University Medical Center. The risk for severe illness and hospitalization in T1DM (BMI $\left.\sim 25 \mathrm{~kg} / \mathrm{m}^{2}\right)$ was 3- to 4-fold higher than in patients without diabetes and similar to that in T2DM. COVID-19 outcome severity in T1DM was related to poor glycemic control within the past year ( $\mathrm{HbA} 1 \mathrm{c} \sim 8 \%$ ), the presence of chronic complications (hypertension, retinopathy, chronic kidney disease, neuropathy), older age, black ethnicity and low socioeconomic status [29]. (e) In a recent study, Ebekozien et al. [30] investigated the prevalence of ketoacidosis among 180 non-Hispanic white, non-Hispanic black and Hispanic subjects with T1DM during COVID-19 infection in 52 clinical sites across the USA. The results showed that non-Hispanic blacks were more prone to develop ketoacidosis, suggesting the role of race and ethnicity. In contrast to non-Hispanic blacks, most of the non-Hispanic white patients were using insulin pumps and continuous glucose monitoring systems (CGMS) in their treatment. (f) In contrast to these reports, Vangoitsenhoven et al. [30] studied the hospitalization needs of 2336 subjects with T1DM from two diabetes specialist centers in the community during the first 3 months of the pandemic in Belgium. Of this cohort, only $0.21 \%$ were admitted to the hospital 
for treatment, suggesting that their risk for severe outcomes was not increased. BMI and $\mathrm{HbA1c}$ in hospitalized vs. non-hospitalized patients were $\sim 24 \mathrm{~kg} / \mathrm{m}^{2}$ vs. $\sim 25.5 \mathrm{~kg} / \mathrm{m}^{2}$ and $\sim 8 \%$ vs. $7.7 \%$, respectively. It should be noted that the vast majority of patients in this study were using CGMS and $25 \%$ of them were on insulin pumps. Research data regarding the effect of COVID-19 infection in a pediatric population with T1DM are scarce. At present, evidence suggests that, contrary to adults, children and adolescents with T1DM infected with SARS-CoV-2 have similar clinical outcomes without increased morbidity and mortality compared to peers without diabetes. A pediatric population with T1DM and COVID-19 infection usually did not require hospitalization [31,32]. Two reports by Rabbone et al. [33] and Unsworth et al. [34] demonstrated that children with type 1 diabetes mellitus and PCR-confirmed SARS-CoV-2 infection presented with mild or no symptoms and did not display long-term adverse outcomes. Regarding the association of COVID-19 infection with the risk of new-onset diabetes, research data are inconsistent. Unsworth et al. in a multicenter study in the UK reported an important increase in new-onset T1DM in children [34]. However, Tittel et al. [35] pointed out that the percentage of new-onset TIDM observed across Germany from March to May 2020 did not differ significantly compared to rates based on data collected over the last decade. In general, several potential factors, alone or in combination, may increase the susceptibility of subjects with T1DM to serious illness following COVID-19 infection.

\section{The Association of T1DM with SARS-CoV2 Infection: Pathophysiological Mechanisms}

The dysregulated metabolic milieu in T1DM exceeds far beyond hyperglycemia; in fact, T1DM is a combination of chronic inflammation and immune dysfunction, which exerts deleterious effects on the vasculature and the coagulation cascade, among others. On the other hand, COVID-19 is a hyperinflammatory condition that ends up as a multi-organ disease. Below, the most prominent connections between the pathophysiology of T1DM and adverse COVID-19 clinical outcomes are presented (Figure 1).

\begin{tabular}{|c|}
\hline T1DM \\
\hline $\begin{array}{l}\text { Compromised cell mediated immunity } \\
\text { - Decreased neutrophil, WBC, basophil, monocyte and } \\
\text { lymphocyte } \\
\text { - Impaired functional properties of neutrophil (decreased } \\
\text { chemotactic and phagocytic capacities, increased apoptosis) } \\
\text { - Impairment in NET formation }\end{array}$ \\
\hline $\begin{array}{ll}\text { Impaired adaptive immunity } \\
\cdot & \text { Decreased Tregs } \\
& \text { IncreasedTh17 } \\
\cdot & \text { Increased activated Th } \\
& \text { Increased pro-inflammatory Th1 subtype } \\
\end{array}$ \\
\hline 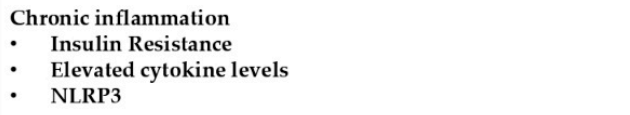 \\
\hline Oxidative stress (imbalance of redox status) \\
\hline $\begin{array}{l}\text { Endothelial Dysfunction } \\
\text { - Increased vascular permeability } \\
\text { - Increased activation of pro-inflammatory cytokines } \\
\text {. Release of pro-coagulant molecules }\end{array}$ \\
\hline Pro-coagulant state \\
\hline Deregulation of ACE2 expression \\
\hline
\end{tabular}

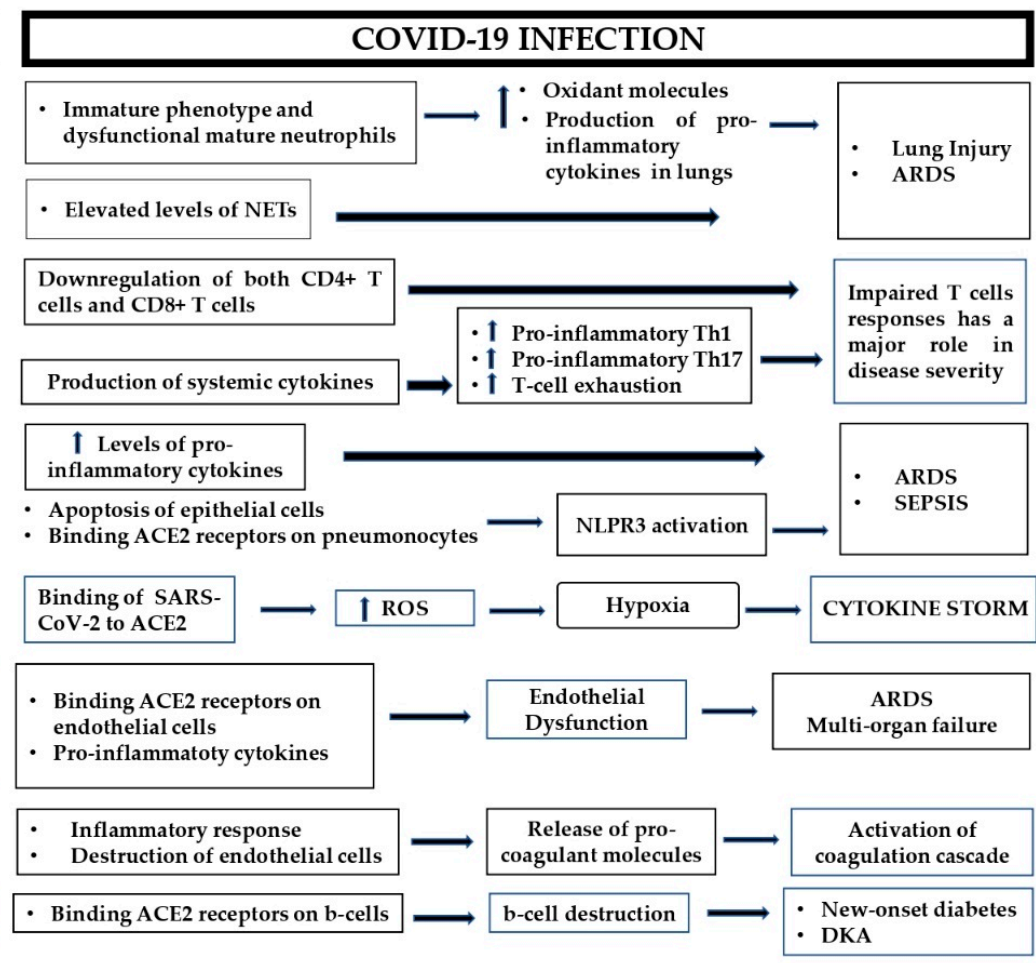

Figure 1. Possible pathophysiological mechanisms responsible for adverse outcomes during COVID-19 infection in patients with type 1 diabetes. ARDS: acute respiratory distress syndrome; ACE2: angiotensin converting enzyme 2; DKA: diabetic ketoacidosis; NET: neutrophil extracellular trap; NLRP3: NOD-like receptor family pyrin domain-containing 3; ROS: reactive oxygen species; Th: T-helper; Tregs: regulatory T-cells; WBC: white blood cells. 


\subsection{Immune Derangement}

Apart from the well-documented role of immune dysregulation in the pathogenesis of T1DM [36], altered immune responses also contribute to the increased susceptibility of diabetic patients to several infections, and presumably SARS-CoV-2. Humoral immunity, which is mediated by macromolecules such as antibodies and complement proteins, does not seem to be seriously aggravated in T1DM; serum antibody titers after vaccination for pneumococcal pneumonia or influenza were similar between diabetic individuals and controls [37,38]. On the contrary, cell-mediated immunity is rather compromised. Despite early data, more recent studies have shown decreased neutrophil numbers in patients with T1DM, a finding that was more prominent at the early stages of the disease [39,40]. Harsunen et al. [41] showed decreased total white blood cells (WBC), neutrophil, basophil, monocyte and lymphocyte counts in 107 adult patients with newly diagnosed type 1 diabetes compared to controls, and the results from Valle et al. [39] were similar, where a mild but significant neutropenia was noted. More importantly, in terms of functional properties, neutrophils have shown decreased chemotactic and phagocytic capacities in T1DM, along with increased rates of apoptosis, with these effects being independent of glycemic control as determined by $\mathrm{HbA1c}$ levels [42,43]. Immature phenotype and dysfunctional mature neutrophils have been recognized as pivotal mediators of severe COVID-19 disease by contributing to the acute respiratory distress syndrome (ARDS) pathophysiology through the enhanced production of potent oxidant molecules, such as superoxide radicals and $\mathrm{H} 2 \mathrm{O} 2$, and by maintaining the inflammatory state in the lungs by triggering the production of pro-inflammatory cytokines [44,45]. In addition, another important neutrophil-mediated mechanism in the pathogenesis of COVID-19 is NETosis [46]. Neutrophils release granular proteins and chromatin fibers to form an extracellular matrix known as neutrophil extracellular trap (NET), which immobilizes and degrades pathogens such as bacteria and viruses and, therefore, contributes to immune defense [47]. A persistent NET formation, however, exerts a pro-inflammatory effect, as is the case in COVID-19, where elevated levels of NETs have been associated with vascular complications, lung injury and disease severity [46]. In a study by Wang et al. in individuals with T1DM, the circulating levels and enzymatic activities of neutrophil elastase (NE) and proteinase 3 (PR3), which are proteins closely associated with elevated formation of NETs, were dramatically elevated, suggesting a state of sustained chronic inflammation similar to COVID-19 [48]. Contrary to this finding, Qin et al. [49] demonstrated reduced levels of these proteins in 44 T1DM individuals as a result of the lower neutrophil numbers, in accordance with other reports where a delayed and impaired NET formation was noticed as a result of hyperglycemia [50,51]. Even a diminished NETosis, however, could be considered a predisposing factor for adverse COVID-19 outcomes, as any impairment in NET formation is a sign of compromised host defense against pathogens.

Even more importantly than impaired innate immunity, defects in adaptive immunity have also been observed in patients with T1DM. Earlier studies in T1DM patients have reported conflicting results regarding Th17 cell populations [52]; however, more recent data have pointed out an imbalance between Th17 and regulatory T (Treg) cells. In a study by Stanisławowska et al. in children with type 1 diabetes, the analysis of Tregs cells in peripheral blood revealed a lower percentage and the absolute number of CD4+Foxp3+ regulatory T-cells compared to controls; on the contrary, a higher frequency and absolute number of CD4+IL17A+ Th17 cells was demonstrated in the patient group [53]. Monocytes isolated directly from the blood of T1DM patients secreted higher amounts of the pro-inflammatory cytokines IL- 6 and IL-1 $\beta$ compared to controls, which are known to induce the expansion of Th17 cell population [54], and a similar effect for IL-1 $\beta$ was demonstrated in peripheral blood mononuclear cells (PBMCs) from children with diabetes [55]. The German Diabetes Study [56] indicated that, in subjects with T1DM, the percentage of activated T-helper and cytotoxic T-cells was higher compared to controls, while the ratio of Treg cells to activated Th cells was lower, implying a defective regulatory capacity, in line with most previous reports $[57,58]$. Indeed, Treg cell responses might be altered in the course of COVID-19 
disease, being increased during the progression to a severe condition and subsequently declining during the progression to a critical condition [59]. A Th1/Th2 imbalance in favor of the pro-inflammatory Th1 subtype with higher activated CD4+CD25+ Th cell subsets has been described in diabetic individuals [60]; however, even in cases where levels of CD4+CD25+ cells are normal, the ability of Tregs to suppress T-cell proliferation was markedly reduced [61]. SARS-CoV-2 infection leads to the downregulation of both CD4+ T-cells and CD8+ T-cells; in addition, the enhanced production of systemic cytokines such as IL-6, IL-1 $\beta$ or CXC Chemokine Ligand 8 (CXCL) leads to skewed T-cell responses, with T-cell exhaustion, hyperactivation of the T helper 1 (Th) subset, and a higher ratio of $\mathrm{T}$ helper 17 cells, both of which have a pro-inflammatory effect $[60,62]$. In general, the imbalance between different T-cell subsets along with impaired T-cell responses in T1DM lead to deficits in adaptive immunity, which could aggravate COVID-19 outcomes.

\subsection{Chronic Inflammation and Oxidative Stress}

Severe, life-threatening COVID-19 disease is characterized by a state of fulminant hypercytokinemia known as "cytokine storm". Most data about the association between this hyperinflammatory condition and diabetes have been derived from studies on type 2 diabetic patients, as insulin resistance, which is the main factor contributing to the pathogenesis of the disease, has long been considered a state of chronic, low-grade inflammation $[21,63]$. This mechanism applies also to T1DM to a significant extent as, despite being primarily characterized by insulin deficiency, it is also commonly associated with prominent insulin resistance, which is related mostly to the peripheral tissues rather than the liver $[64,65]$. Regarding insulin resistance especially at the level of adipose tissue, various studies have shown higher circulating free fatty acid (FFA) and glycerol levels during low-dose hyperinsulinemic and euglycemic clamps, indicating a lower rate of insulin-mediated lipolysis regardless of glycemic control [66]. Increased FFAs activate Toll-like receptor-4 (TLR-4) in adipocytes and macrophages, thus upregulating NF-kB signaling and increasing the production of pro-inflammatory cytokines such as TNF- $\alpha$ [67]. Levels of omentin-1, an adipokine that downregulates the expression of NF-kB and TNF- $\alpha$ and inhibits lipopolysaccharide (LPS)-induced inflammation, are decreased in T1DM [68]; in the same notion, levels of adiponectin, an adipokine that also inhibits TNF-a-induced activation of NF-kB signaling and endothelial adhesion molecule expression, are diminished during hyperglycemic states and are negatively associated with insulin resistance [69]. Studies in mice have shown that the dysfunctional adipose tissue in T1DM results in decreased synthesis of pro-resolving lipid mediators, such as lipoxins, leading to the impaired resolution of chronic inflammation [70]. Even in the absence of insulin resistance, however, chronic inflammation with elevated cytokine levels has been demonstrated in many studies with T1DM subjects. In a study by Gouda et al. [71], serum levels of IL-1 $\alpha$ and IL-1 $\beta$ were elevated in T1DM patients in an age-dependent manner, in accordance with the findings by Dogan et al. [72], where elevated levels of IL-1 $\beta$, IL-2, IL-6, and TNF-a were reported in 27 children with T1DM compared to controls. Regarding IL-6, which is secreted by T-cells and macrophages and plays a crucial role in the pathogenesis of COVID-19 complications, a recent study by Talaat et al. [73] showed higher levels in diabetic children compared to controls, a finding that was confirmed in the studies by Bradshaw et al. [54] and Ururahy et al. [74], which showed higher secretions from monocytes and higher IL-6 mRNA levels in peripheral blood leukocytes in T1DM patients compared to controls, respectively. In a subset of the DCCT/EDIC cohort, where biomarkers were measured at four time points over 20 years in 886 T1DM patients, IL-6, along with tumor necrosis factor receptor-1 and -2 , active and total plasminogen activator inhibitor-1 (PAI-1), adhesion molecules and acute-phase reactants, namely fibrinogen and C-reactive protein (CRP), were increased throughout the study period [75]. In patients with T1DM without macrovascular disease, monocyte IL-6 levels were increased compared to controls both in the resting state and after lipopolysaccharide activation, with the latter being the case also for IL-1 $\beta$ [76]. Lastly, regarding TNF- $\alpha$, the stimulation of PBMCs in T1DM patients with high-M alginate and 
lipopolysaccharides (LPS) induced a significantly increased TNF production compared to controls [77], and Hussain et al. [78] showed a substantial hypersecretion of IL-1 $\alpha$ and TNF- $\alpha$ from PBMCs both in 29 T1DM children and their healthy first-degree relatives. More importantly, in a case-control study from the EURODIAB Prospective Complications Study of 543 individuals with T1DM, plasma levels of CRP, IL-6, TNF- $\alpha$, VCAM, and Eselectin were significantly higher in patients with macrovascular complications compared to those without [79], suggesting the role of chronic inflammation in the pathogenesis of diabetic micro- and macrovascular complications, which, in turn, have been considered the major risk factor of adverse COVID-19 outcomes in many cohorts. In general, the natural history of COVID-19 encompasses excessive circulating levels of pro-inflammatory cytokines such as IL-1 $\beta$, IL-6, IL-7, IL-8, IL-17, interferon gamma (IFN $\gamma$ ), TNF- $\alpha$, CXCL10 and monocyte chemoattractant protein-1 (MCP-1), and is associated with progression to ARDS, sepsis and acute mortality [80,81]. In fact, the presence of increased levels of IL-1 $\beta$ in patients with COVID-19 infection revealed that the inflammatory process is preceded by cell pyroptosis, which is mediated through the activation of the NOD-like receptor family pyrin domain-containing 3 (NLRP3) inflammasome [67]. T1DM-related oxidative stress, mediated through the increased production of ROS and AGEs, induces the formation of the NLRP3 inflammasome through the activation of the NF-kB pathway [82]. At the same time, SARS-CoV-2 activates the inflammasome through various mechanisms. More specifically, as SARS-CoV-2 enters the alveolar epithelial cells, it leads to their apoptosis, which, in turn, leads to the release of molecules that trigger NRP3 activation of the alveolar macrophages [83]. The virus also activates the inflammasome by binding ACE2 receptors on pneumonocytes, while its $\mathrm{N}$ proteins activate the complement cascade and release the C3a and C5a anaphylatoxins, which induce inflammasome activation as well [84].

Apart from inflammation, oxidative stress is a key player in COVID-19; in fact, it is the interplay between these two pathways that determines disease severity [85] (Figure 2). Oxidative stress is a state of imbalance between the production of ROS and antioxidant defenses that inactivates these free radicals [86]. ROS includes superoxide radicals $\left(\mathrm{O}_{2}{ }^{\bullet-}\right)$, hydrogen peroxide $\left(\mathrm{H}_{2} \mathrm{O}_{2}\right)$, hydroxyl radicals $\left({ }^{\bullet} \mathrm{OH}\right)$, and singlet oxygen $\left({ }^{1} \mathrm{O}_{2}\right)$, all necessary by-products of mainly mitochondrial metabolism that do become harmful when accumulating at high levels. To defend themselves from the deleterious effects of these mediators, cells produce enzymatic antioxidants including mainly superoxide dismutase (SOD), catalase (CAT), and glutathione peroxidase (GPx), which delay or even utterly inhibit the oxidization process [87]. Hyperglycemia, the prominent feature of T1DM, has long been known to be a potent mediator of oxidative stress through four distinct pathways [88]: (a) the increased flux of the polyol pathway, which leads to the depletion of glutathione (GSH), a potent antioxidant, (b) the activation of protein kinase C (PKC), which leads to increased activity of NADPH oxidases, (c) the increased intracellular production of advanced glycation end products (AGEs), which leads to the glycation of certain proteins that bind to AGE receptors (RAGE) and activate nuclear factor kappa B (NF-kB) and other inflammatory pathways, and (d) the increased activity of the hexosamine pathway, leading to the production of UDP-N-acetyl glucosamine, which modifies functionally important proteins and, eventually, gene expression. The cumulative effect of these pathways is the overproduction of superoxide from the mitochondria, which promotes endothelial dysfunction and the subsequent release of pro-inflammatory cytokines and adhesion molecules from the damaged cells [89]. Many studies have demonstrated the presence of oxidative stress markers in patients with T1DM. In a study by Fatima et al. [90], the activity of antioxidant enzymes in plasma such as superoxide dismutase, catalase, and glutathione reductase was significantly downregulated in 29 T1DM subjects compared to healthy controls, with a concomitant increase in the levels of pro-inflammatory cytokines IL- $1 \beta$, IL-17A, IL-23, IFN- $\gamma$ and TNF- $\alpha$. Malondialdehyde (MDA) [91] and protein carbonyl (PC) [92], which are reliable biomarkers of oxidative stress, were found to be elevated in the plasma of T1DM patients, indicating enhanced polyunsaturated fatty acid peroxidation and free radical-mediated protein damage. In a study including 35 patients with T1DM 
and 28 age- and sex-matched normal subjects, MDA level was significantly elevated in diabetic patients, while the level of GSH and the ferric reducing ability of plasma (FRAP) were lower in patients than in controls, and these findings were associated with poorer glycemic control [91]. This finding about GSH has been observed in a number of studies showing decreased intracellular glutathione concentrations in both the plasma and erythrocytes of patients with T1DM $[93,94]$, and the same applies to other antioxidant molecules such as catalase (CAT) [95] and superoxide dismutase (SOD) [96]. The imbalance of redox status that is observed in T1DM [97] leads to altered immune responses and increased levels of proinflammatory cytokines that are key constituents of the "cytokine storm", such as IL-1 $\beta$. During COVID-19 infection, the high affinity and the consequent binding of SARS-CoV-2 to angiotensin-converting enzyme 2 (ACE2) increases angiotensin II availability and upregulates nicotinamide adenine dinucleotide phosphate (NADPH) oxidase (NOX) activation, which leads to the increased production of reactive oxygen species (ROS) $[98,99]$. ROS, in turn, increases iNOS expression via NF- $\kappa B$ activation and, therefore, increases NO formation, which results in cytopathic hypoxia [100]. This hypoxia, which is a common manifestation of sepsis, triggers the formation of free radicals through the mitochondrial respiratory chain, an event that eventually leads to the upregulation of pro-inflammatory cytokines that, in a vicious cycle, activate macrophages and neutrophils to produce more free radicals [101]. Oxidative stress converts soluble plasma fibrinogen into abnormal fibrin clots, resulting in microthrombosis, while the attack of SARS-CoV-2 against hemoglobin groups in the erythrocyte leads to the release of heme and free iron ions into the bloodstream, further contributing to ROS production and mitochondrial damage [102].

\subsection{Endothelial Dysfunction}

The endothelium plays a vital role in several physiological processes; it regulates the tone of vascular smooth muscle by the release of vasodilators and vasoconstrictors, controls vascular permeability, and is an important mediator of inflammation and coagulation by regulating the adhesion of leucocytes and platelets [103-105]. The endothelial glycocalyx is an endothelial surface layer that consists of proteoglycans and glycoproteins and prevents the direct contact of blood cells with the endothelial surface [106].

According to several research data, T1DM is associated with endothelial dysfunction [107-109]. A cross-sectional study showed that endothelial function assessed by flow-mediated dilation (FMD) is impaired in patients with T1DM compared to healthy individuals, even in patients with disease duration less than five years [107]. Jarvisalo et al. reported that $16(36 \%)$ out of 45 patients with T1DM displayed lower peak FMD response and increased carotid intima-mediated thickness, suggesting that endothelial dysfunction may be an indicator for the development of premature atherosclerosis [108]. Another study by Machnica et al. reported that markers of endothelial destruction, including intercellular adhesion molecule-1 (ICAM-1), VCAM-1, E-selectin, TNF-a and IL-6, were significantly increased in patients with T1DM and disease duration $5.13 \pm 2.18$ years compared to controls, indicating that endothelial dysfunction is present early in the course of T1DM [109]. Endothelial dysfunction and endothelial glycocalyx damage increase leucocyte and circulating inflammatory cells' adhesion, and promote vascular permeability and coagulation [110-113]. The pathogenesis of the impairment of the endothelial micromilieu in patients with T1DM is closely related to hyperglycemia and subsequent oxidative stress [70]. The passive diffusion of glucose into the endothelial cells and the subsequent intracellular accumulation of glucose during acute and long-term hyperglycemia activates sorvitol, protein kinase $\mathrm{C}$, and pentose phosphate pathways, and increases the $\mathrm{NADPH} /$ nicotinamide adenine dinucleotide (NAD) rate. These alterations reduce the availability of nitric acid, increase vascular permeability, promote an inflammatory response via the activation of cytokines and adhesion molecules, and contribute to endothelial cells apoptosis and endothelial dysfunction $[70,114,115]$. The destroyed endothelial cells release pro-coagulant molecules (von Willebrand factor, PAI-1 and tromboxan A2) and express 
adhesion molecules including P-selectin, E-selectin, VCAM-1, and ICAM-1, which contribute to the adhesion of neutrophils and platelets to endothelium [116]. Hyperglycemia and the subsequent production of advanced-glycation end products are associated with the increased expression of pro-inflammatory cytokines including IL-6, TNF- $\alpha$ and IL1 , which enhance the expression of pro-coagulant molecules and inhibit the release of anti-coagulant molecules (thrombomodulin) by endothelial cells [117-119]. Consequently, endothelial derangement promotes a pro-inflammatory and a pro-coagulant state.

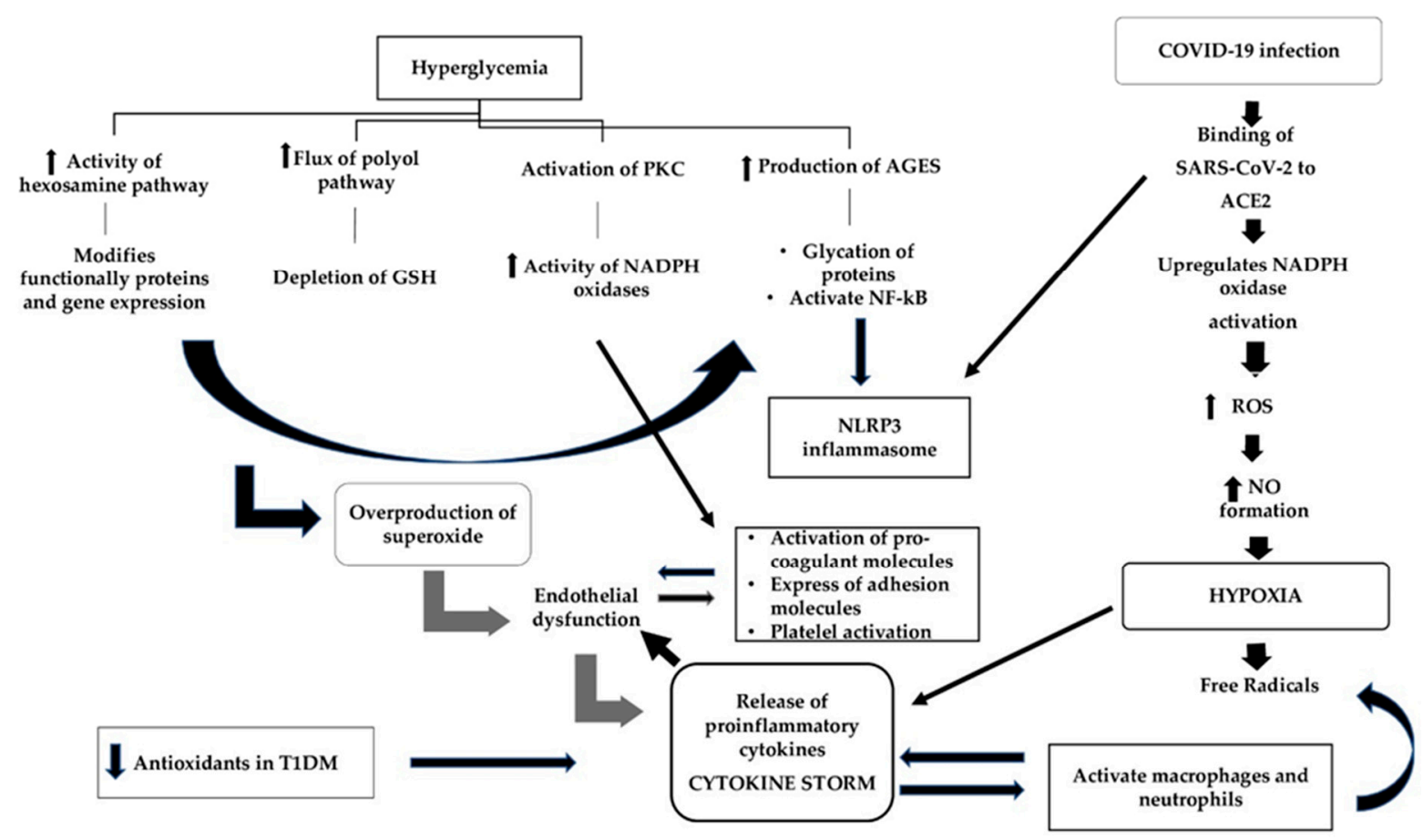

Figure 2. The mechanisms of oxidative stress leading to adverse clinical outcomes during COVID-19 infection in patients with type 1 diabetes mellitus. In T1DM, hyperglycemia is a potent mediator of oxidative stress through four different pathways whose accumulative effect is the overproduction of superoxide, which leads to endothelial dysfunction and the subsequent release of pro-inflammatory cytokines. The destroyed endothelial cells release pro-coagulant molecules and express adhesion molecules. Simultaneously, hyperglycemia through the activation of the PKC pathway increases the expression of adhesion molecules, contributing additionally to endothelial dysfunction, and this leads to platelet activation and aggregation. During COVID-19 infection, the binding of SARS-CoV-2 to angiotensin-converting enzyme 2 (ACE2) results in the increased production of reactive oxygen species (ROS), which in turn increases NO formation and leads to cytopathic hypoxia. Hypoxia via the formation of free radicals upregulates the release of pro-inflammatory cytokines, which promotes endothelial derangement and contributes to pro-coagulability. Additionally, the upregulation of proinflammatory cytokines, in a vicious cycle, activate macrophages and neutrophils to produce more free radicals. Neutrophils have been recognized as pivotal mediators of severe COVID-19 disease by triggering the production of pro-inflammatory cytokines and maintaining the inflammatory state in the lungs. AGEs: advanced glycation end products; GSH: glutathione; NADPH: nicotinamide adenine dinucleotide phosphate; NF-kB: nuclear factor-kB; NLRP3: NOD-like receptor family pyrin domain-containing 3; NO: nitric oxide; PKC: protein kinase C; ROS: reactive oxygen species.

SARS-CoV-2 affects the vascular system directly by targeting endothelial cells through ACE2 receptor binding, leading to severe endothelial derangement and inflammation [120-122]. In addition, the overproduction of pro-inflammatory cytokines during COVID-19 promotes endothelial dysfunction [83]. Chen et al. demonstrated that patients with severe COVID-19 disease displayed increased levels of pro-inflammatory cytokines, including soluble interleukin 2 receptor (IL-2R), IL-6, and TNF-a [7]. IL-6 promotes endothelial derangement and contributes to pro-coagulability $[123,124]$. Furthermore, the inflammatory-mediated damage of glycocalyx by IL- 6 or TNF- $\alpha$ increases vascular permeability inducing interstitial fluid shift and generalized edema [125]. 
The infected endothelial cells release increased levels of proinflammatory cytokines, which induce the immune-mediated damage of lungs and other organs resulting in ARDS and multi-organ failure [126]. Histological studies showed that endothelial cells damaged by SARS-CoV-2 result in vasculitis and endothelitis in multiple organs [127-129]. Postmortem histological reports from three patients gave the first evidence of the role of endothelium in the pathogenesis of COVID-19 disease, and provided evidence of endothelitis during the course of the infection. The authors suggested that the clinical presentation of COVID-19 might be worse in vulnerable patients with pre-existing endothelial dysfunction [127]. Copin et al. showed that endothelial derangement induces the vascular damage of small to medium-sized pulmonary arteries, contributing to lung injury in severe COVID-19 disease [129].

A chronic endothelial dysfunction predisposes one to severe COVID-19 infection by inducing alterations at the glycocalyx and endothelial cells, leading to increased leucocyte adhesion and promoting a procoagulant and antifibrinolytic state. Chronic endothelial dysfunction due to T1DM in combination with the direct damage of endothelial cells by SARS-CoV-2 may result in endothelial and microcirculation impairment, which contribute to the pathogenesis of acute respiratory syndrome and multi-organ failure.

\subsection{Coagulopathy}

Type 1 diabetes mellitus is associated with a hypercoagulant state, which is characterized by the deregulation of clotting and fibrinolytic activity. One responsible mechanism for these derangements is the alteration in the concentration and activity of several coagulatory proteins, mainly due to hyperglycemia [130]. According to research data, several pro-coagulant proteins, including von Willebrand factor, prothrombin, and fibrinogen, are increased in T1DM [131-134]. Additionally, plasmin presents reduced activity due to the increased glycation of plasminogen, the precursor of plasmin [135]. Simultaneously, the concentrations of anti-coagulant proteins, including protein $\mathrm{C}$ and protein $\mathrm{S}$, are reduced $[136,137]$. The activity of antithrombin is also impaired by methylglyoxal, a by-product of hyperglycemia [138]. Regarding the anti-fibrinolytic proteins, the concentrations of thrombin-activatable fibrinolysis inhibitor and 2-macroglobulin are elevated in patients with T1DM $[139,140]$. The aforementioned derangements in coagulatory proteins concentrations and activity exert a negative impact on fibrin clot formation and clot lysis parameters, resulting in a pro-coagulant state that increases the risk of thrombosis [130]. Another mechanism responsible for the hypercoagulability state in T1DM is the hyperactivation of platelets. Hyperglycemia induces the reduction of nitric acid and prostacyclin production by endothelial cells, leading to an imbalance in platelet activity inhibition [141]. Additionally, hyperglycemia and the subsequent increase in oxidative stress activates the PKC pathway, which contributes to platelet activation and aggregation $[142,143]$. The glycation of proteins at the surface of platelets ameliorates the sensitivity of platelets to thrombin and increases platelets adhesion [144]. Consequently, hyperglycemia is the main mediator which, through the imbalance of coagulatory proteins and the hyperactivation of platelets, promotes a hypercoagulability state in T1DM.

A significant quantity of research data regarding COVID-19 patients showed that SARS-CoV-2 infection is associated with hypercoagulation in multiple organs, as denoted by increased levels of D-dimers and fibrinogen degradation products $[145,146]$. Zhou et al. reported that 117 (68\%) out of 172 patients with COVID-19 infection presented increased activation of coagulation, as indicated by high levels of D-dimer concentrations. Interestingly, D-dimer concentrations above $1 \mu \mathrm{g} / \mathrm{mL}$ were associated with an 18 times increased odds ratio for a fatal outcome [145]. A study by Klok et al. with 184 ICU patients pointed out that $31 \%$ of the patients presented thrombotic complications including venous thromboembolism $(27 \%)$ and arterial embolism (3\%), despite systematic thrombosis prophylaxis [147]. A retrospective study from China including 183 patients highlighted that $71 \%$ of patients met clinical criteria for disseminated intravascular coagulation (DIC), and that impaired coagulation parameters (D-dimers, fibrin degradation product, prothrombin time, fibrinogen 
and antithrombin activity) are significantly associated with prognosis [148]. An autopsy study in skin and lung tissues from five individuals with severe COVID-19 infection identified a generalized microvascular thrombotic injury [149]. Profound inflammatory response and the activation of cytokine storm in COVID-19 infection, in conjunction with the destruction of the endothelial cells with the subsequent release of pro-coagulant molecules, contribute to the activation of the coagulation cascade.

\subsection{The Role of ACE2}

Angiotensin-converting enzyme (ACE) is the key mediator of the renin angiotensin aldosterone system (RAAS) by converting angiotensin I to II. ACE2 is a novel homolog of ACE that degrades mainly angiotensin II, and to a lesser extent angiotensin I to angiotensin I-VII and angiotensin I-IX [150,151]. According to research data, angiotensin I-VII ameliorates vasodilation, stimulates bradykinin release, inhibits ACE, and subsequently diminishes vasoconstriction mediated by angiotensin II. Thus, angiotensin I-VII seems to be an important modulator of the RAAS [152,153]. The decreased ACE2 expression results in increasing vascular permeability by the activation of the kallikrein-bradykinin pathway [154]. Additionally, ACE2 and angiotensin I-VII physiologically seem to display important anti-inflammatory and anti-oxidant properties [155]. The reduction in ACE2 expression leads to cellular damage and hyperinflammation.

ACE2 is expressed in various human tissues, including lungs, hearts, kidneys, intestine and blood cells. Angiotensin-converting enzyme 2 (ACE2) receptors have been identified as the main target of the SARS-CoV-2 spike protein, permitting the entrance of the virus in host cells. [120,151]. According to research data, chronic hyperglycemia leads to the downregulation of ACE2 expression, rendering the host cells susceptible to the inflammatory and damaging effect of the SARS-CoV-2 [156]. On the other hand, acute hyperglycemia upregulates ACE2 expression, which enables increased virus entry into the cells [157]. A study with mouse models of diabetes showed that the expression of ACE2 receptors is increased in multiple tissues [158]. This deregulation of ACE2 expression results in both an increased risk of COVID-19 infection and adverse outcomes of the disease. ACE2 is also expressed in pancreatic b-cells, which may permit the direct damage of b-cell function [159]. A recent study by Muller et al. showed that SARS-CoV-2 infects and replicates in cultured human islets, inducing morphological and functional abnormalities such as impairment in glucose responsiveness [160]. Similarly, another study highlighted that SARS-CoV-2-associated b-cell infection leads to inflammatory cytokine release, b-cell apoptosis and decreased insulin secretion [161]. Type 1 diabetes results from auto-immune destruction and primary losses of b-cell mass; however, residual b-cell function is retained in many individuals for decades after clinical diagnosis, contributing to glycemic control [162]. The binding of SARS-CoV-2 to ACE2 receptors of b-cells may lead to the destruction of the remaining b-cells and to subsequent complete insulin deficiency, which contributes to the development of severe ketoacidosis. Indeed, $\mathrm{Li}$ et al. reported that $6.4 \%$ of patients with COVID-19 and $11.6 \%$ of patients with COVID-19 and diabetes presented ketosis, which resulted in a high mortality rate (33.3\%). The authors concluded that COVID-19 infection leads to the development of ketosis or DKA in patients without diabetes, and induces DKA in patients with diabetes [163]. The Italian Society of Pediatric Endocrinology and Diabetes reported that the percentage of children with severe DKA rose from $36.1 \%$ to $44.3 \%$ during the early phase of COVID-19 [33]. Similarly, a multicenter study from Germany reported that the incidence of DKA in 532 children and adolescents with T1DM was $44.7 \%$ during the COVID-19 period in 2020, which was significantly higher compared to the two previous years [164]. On the other hand, the direct damage of pancreatic cells by SARS-CoV-2 may contribute to the development of new-onset diabetes. A recent case report presented a 19-year-old German male who was hospitalized with DKA and insulin-dependent diabetes in the absence of typical type 1 diabetes autoantibodies, 5 to 7 weeks after asymptomatic COVID-19 infection [165]. Another case report described a patient who presented DKA and was diagnosed with T1DM at the onset of COVID-19 infection [166]. A multicenter study 
in the UK was the first that reported an important increase in new-onset T1DM in children, with evidence of SARS-CoV-2 infection or exposure in some of these [34]. Research data regarding the effect of other coronavirus outbreaks showed that SARS-associated b-cell damage causes acute hyperglycemia, even among people without diabetes. Approximately $50 \%$ of SARS patients who had no previous diabetes and received no steroid treatment developed diabetes during hospitalization, and after 3 years, $5 \%$ of the patients still had diabetes. These findings support the probability of chronic damage to b-cells [167].

\section{Conclusions}

A growing number of studies have demonstrated that T1DM is an important risk factor affecting the clinical severity of COVID-19 disease. Immune and inflammatory dysregulation in conjunction with increased oxidative stress render patients with T1DM susceptible to severe COVID-19 infection. Additionally, the chronic endothelial dysfunction and the hypercoagulant state observed in T1DM account for the generalized endothelitis and thrombotic events that culminate in multi-organ failure and death. The deregulation of ACE2 expression in T1DM results in both increased risk of COVID-19 infection and in adverse outcomes of the disease. Apart from its role in viral transmission, the ACE2 receptor could also contribute to the development of new-onset diabetes and the induction of DKA in patients with T1DM. Large clinical studies are required to identify the clinical and biochemical parameters that could help identify patients at greater risk so that, along with a better understanding of the underlying pathophysiological mechanisms, more precise, timely and individualized therapeutic decisions can be made.

Author Contributions: A.K., E.K., G.D. and V.L.: structuring of the review, writing, and literature review; I.I., A.R., N.T.: assistance with writing. G.D. and V.L. equally contributed to all stages of the manuscript preparation. All authors have read and agreed to the published version of the manuscript.

Funding: This research received no external funding.

Conflicts of Interest: The authors report no conflict of interest.

$\begin{array}{ll}\text { Abbreviations } \\ \text { ACE2 } & \begin{array}{l}\text { angiotensin-converting enzyme 2 } \\ \text { advanced glycation end products }\end{array} \\ \text { AGEs } & \begin{array}{l}\text { acute respiratory distress syndrome } \\ \text { ARDS }\end{array} \\ \text { BMI } & \text { body mass index } \\ \text { CAT } & \text { catalase } \\ \text { CGMS } & \text { continuous glucose monitoring systems } \\ \text { COVID-19 } & \text { coronavirus disease } \\ \text { CRP } & \text { C-reactive protein } \\ \text { CXCL } & \text { CXC chemokine ligand } \\ \text { DIC } & \text { disseminated intravascular coagulation } \\ \text { DKA } & \text { diabetic ketoacidosis } \\ \text { FMD } & \text { flow-mediated dilation } \\ \text { FRAP } & \text { ferric reducing ability of plasma } \\ \text { GSH } & \text { glutathione } \\ \text { ICAM-1 } & \text { intracellular adhesion molecule 1 } \\ \text { IFN- } \gamma & \text { interferon gamma } \\ \text { IL } & \text { interleukin } \\ \text { IR } & \text { insulin resistance } \\ \text { LPS } & \text { lipopolysaccharide } \\ \text { MCP-1 } & \text { monocyte chemoattractant protein-1 } \\ \text { MDA } & \text { malondialdehyde } \\ \text { NAD } & \text { nicotinamide adenine dinucleotide } \\ \text { NADPH } & \text { nicotinamide adenine dinucleotide phosphate } \\ \text { NE } & \text { neutrophil elastase }\end{array}$




$\begin{array}{ll}\text { NET } & \text { neutrophil extracellular trap } \\ \text { NF-kB } & \text { nuclear factor-kB } \\ \text { NLRP3 } & \text { NOD-like receptor family pyrin domain-containing 3 } \\ \text { NO } & \text { nitric oxide } \\ \text { NOX } & \text { oxidase } \\ \text { OS } & \text { oxidative stress } \\ \text { PAI-1 } & \text { plasminogen activator inhibitor-1 } \\ \text { PBMC } & \text { peripheral blood mononuclear cells } \\ \text { PC } & \text { protein carbonyl } \\ \text { PKC } & \text { protein kinase C } \\ \text { PR3 } & \text { proteinase 3 } \\ \text { RAAS } & \text { renin angiotensin aldosterone system } \\ \text { RAGE } & \text { advanced glycation end products receptors } \\ \text { ROS } & \text { reactive oxygen species } \\ \text { SARS } & \text { severe acute respiratory syndrome } \\ \text { SARS-CoV-2 } & \text { severe acute respiratory syndrome coronavirus 2 } \\ \text { SOD } & \text { superoxide dismutase } \\ \text { T1DM } & \text { type } 1 \text { diabetes mellitus } \\ \text { T2DM } & \text { type 2 diabetes mellitus } \\ \text { Th } & \text { T-helper } \\ \text { TNF- } \alpha & \text { tumor necrosis factor alpha } \\ \text { Treg } & \text { T regulatory } \\ \text { VCAM } & \text { vascular cell adhesion molecule } \\ \text { WBC } & \text { white blood cells } \\ \text { WHO } & \text { World Health Organization } \\ & \end{array}$

\section{References}

1. Zhou, P.; Yang, X.L.; Wang, X.G.; Hu, B.; Zhang, L.; Zhang, W.; Si, H.R.; Zhu, Y.; Li, B.; Huang, C.L.; et al. A pneumonia outbreak associated with a new coronavirus of probable bat origin. Nature 2020, 579, 270-273. [CrossRef]

2. Huang, C.; Wang, Y.; Li, X.; Ren, L.; Zhao, J.; Hu, Y.; Zhang, L.; Fan, G.; Xu, J.; Gu, X.; et al. Clinical features of patients infected with 2019 novel coronavirus in Wuhan, China. Lancet 2020, 395, 497-506. [CrossRef]

3. World Health Organization. WHO Director-General's opening remarks at the media briefing on COVID-19-11 March 2020. WHO Director General'speeches. Available online: https://www.who.int/director-general/speeches/detail/who-directorgeneral-s-opening-remarks-at-the-media-briefing-on-covid-19---11-march-2020 (accessed on 18 March 2021).

4. Wu, Z.; McGoogan, J.M. Characteristics of and Important Lessons from the Coronavirus Disease 2019 (COVID-19) Outbreak in China: Summary of a Report of 72314 Cases From the Chinese Center for Disease Control and Prevention. JAMA 2020, 323, 1239-1242. [CrossRef]

5. Chen, N.; Zhou, M.; Dong, X.; Qu, J.; Gong, F.; Han, Y.; Qiu, Y.; Wang, J.; Liu, Y.; Wei, Y.; et al. Epidemiological and clinical characteristics of 99 cases of 2019 novel coronavirus pneumonia in Wuhan, China: A descriptive study. Lancet 2020, 395, 507-513. [CrossRef]

6. Yang, J.; Zheng, Y.; Gou, X.; Pu, K.; Chen, Z.; Guo, Q.; Ji, R.; Wang, H.; Wang, Y.; Zhou, Y. Prevalence of comorbidities and its effects in patients infected with SARS-CoV-2: A systematic review and meta-analysis. Int. J. Infect. Dis. 2020, 94, 91-95. [CrossRef] [PubMed]

7. Chen, G.; Wu, D.; Guo, W.; Cao, Y.; Huang, D.; Wang, H.; Wang, T.; Zhang, X.; Chen, H.; Yu, H.; et al. Clinical and immunological features of severe and moderate coronavirus disease 2019. J. Clin. Investig. 2020, 130, 2620-2629. [CrossRef]

8. Docherty, A.B.; Harrison, E.M.; Green, C.A.; Hardwick, H.E.; Pius, R.; Norman, L.; Holden, K.A.; Read, J.M.; Dondelinger, F.; Carson, G.; et al. ISARIC4C investigators. Features of 20133 UK patients in hospital with covid-19 using the ISARIC WHO Clinical Characterisation Protocol: Prospective observational cohort study. BMJ 2020, 369, m1985. [CrossRef] [PubMed]

9. Li, B.; Yang, J.; Zhao, F.; Zhi, L.; Wang, X.; Liu, L.; Bi, Z.; Zhao, Y. Prevalence and impact of cardiovascular metabolic diseases on COVID-19 in China. Clin. Res. Cardiol. 2020, 109, 531-538. [CrossRef] [PubMed]

10. CDC COVID-19 Response Team. Preliminary estimates of the prevalence of selected underlying health conditions among patients with coronavirus disease 2019-United States, February 12-March 28, 2020. MMWR Morb Mortal Wkly. Rep. 2020, 69, 382-386. [CrossRef] [PubMed]

11. Zhang, Y.; Cui, Y.; Shen, M.; Zhang, J.; Liu, B.; Dai, M.; Chen, L.; Han, D.; Fan, Y.; Zeng, Y.; et al. Medical team from Xiangya Hospital to support Hubei, China. Association of diabetes mellitus with disease severity and prognosis in COVID-19: A retrospective cohort study. Diabetes Res. Clin. Pract. 2020, 165, 108227. [CrossRef]

12. Kumar, A.; Arora, A.; Sharma, P.; Anikhindi, S.A.; Bansal, N.; Singla, V.; Khare, S.; Srivastava, A. Is diabetes mellitus associated with mortality and severity of COVID-19? A meta-analysis. Diabetes Metab Syndr. 2020, 14, 535-545. [CrossRef] 
13. Lim, S.; Bae, J.H.; Kwon, H.S.; Nauck, M.A. COVID-19 and diabetes mellitus: From pathophysiology to clinical management. Nat. Rev. Endocrinol. 2021, 17, 11-30. [CrossRef]

14. Holman, N.; Knighton, P.; Kar, P.; O’Keefe, J.; Curley, M.; Weaver, A.; Barron, E.; Bakhai, C.; Khunti, K.; Wareham, N.J.; et al. Risk factors for COVID-19-related mortality in people with type 1 and type 2 diabetes in England: A population-based cohort study. Lancet Diabetes Endocrinol. 2020, 8, 823-833. [CrossRef]

15. Ebekozien, O.A.; Noor, N.; Gallagher, M.P.; Alonso, G.T. Type 1 Diabetes and COVID-19: Preliminary Findings from a Multicenter Surveillance Study in the U.S. Diabetes Care 2020, 43, e83-e85. [CrossRef]

16. Brufsky, A. Hyperglycemia, hydroxychloroquine, and the COVID-19 pandemic. J. Med. Virol. 2020, 92, 770-775. [CrossRef] [PubMed]

17. Yang, J.K.; Feng, Y.; Yuan, M.Y.; Yuan, S.Y.; Fu, H.J.; Wu, B.Y.; Sun, G.Z.; Yang, G.R.; Zhang, X.L.; Wang, L.; et al. Plasma glucose levels and diabetes are independent predictors for mortality and morbidity in patients with SARS. Diabetes Med. 2006, 23, 623-628. [CrossRef]

18. Boddu, S.K.; Aurangabadkar, G.; Kuchay, M.S. New onset diabetes, type 1 diabetes and COVID-19. Diabetes Metab. Syndr. 2020, 14, 2211-2217. [CrossRef] [PubMed]

19. Williamson, E.J.; Walker, A.J.; Bhaskaran, K.; Bacon, S.; Bates, C.; Morton, C.E.; Curtis, H.J.; Mehrkar, A.; Evans, D.; Inglesby, P.; et al. Factors associated with COVID-19-related death using OpenSAFELY. Nature 2020, 584, 430-436. [CrossRef] [PubMed]

20. Bode, B.; Garrett, V.; Messler, J.; McFarland, R.; Crowe, J.; Booth, R.; Klonoff, D.C. Glycemic Characteristics and Clinical Outcomes of COVID-19 Patients Hospitalized in the United States. J. Diabetes Sci. Technol. 2020, 14, 813-821. [CrossRef]

21. Huang, I.; Lim, M.A.; Pranata, R. Diabetes mellitus is associated with increased mortality and severity of disease in COVID-19 pneumonia-A systematic review, meta-analysis, and meta-regression. Diabetes Metab. Syndr. 2020, 14, 395-403. [CrossRef]

22. Seiglie, J.; Platt, J.; Cromer, S.J.; Bunda, B.; Foulkes, A.S.; Bassett, I.V.; Hsu, J.; Meigs, J.B.; Leong, A.; Putman, M.S.; et al. Diabetes as a Risk Factor for Poor Early Outcomes in Patients Hospitalized With COVID-19. Diabetes Care 2020, 43, 2938-2944. [CrossRef] [PubMed]

23. Scheen, A.J.; Marre, M.; Thivolet, C. Prognostic factors in patients with diabetes hospitalized for COVID-19: Findings from the CORONADO study and other recent reports. Diabetes Metab. 2020, 46, 265-271. [CrossRef]

24. Apicella, M.; Campopiano, M.C.; Mantuano, M.; Mazoni, L.; Coppelli, A.; Del Prato, S. COVID-19 in people with diabetes: Understanding the reasons for worse outcomes. Lancet Diabetes Endocrinol. 2020, 8, 782-792. [CrossRef]

25. Barron, E.; Bakhai, C.; Kar, P.; Weaver, A.; Bradley, D.; Ismail, H.; Knighton, P.; Holman, N.; Khunti, K.; Sattar, N.; et al. Associations of type 1 and type 2 diabetes with COVID-19-related mortality in England: A whole-population study. Lancet Diabetes Endocrinol. 2020, 8, 813-822. [CrossRef]

26. Carey, I.M.; Critchley, J.A.; DeWilde, S.; Harris, T.; Hosking, F.J.; Cook, D.G. Risk of Infection in Type 1 and Type 2 Diabetes Compared With the General Population: A Matched Cohort Study. Diabetes Care 2018, 41, 513-521. [CrossRef]

27. McGurnaghan, S.J.; Weir, A.; Bishop, J.; Kennedy, S.; Blackbourn, L.A.K.; McAllister, D.A.; Hutchinson, S.; Caparrotta, T.M.; Mellor, J.; Jeyam, A.; et al. Public Health Scotland COVID-19 Health Protection Study Group; Scottish Diabetes Research Network Epidemiology Group. Risks of and risk factors for COVID-19 disease in people with diabetes: A cohort study of the total population of Scotland. Lancet Diabetes Endocrinol. 2021, 9, 82-93. [CrossRef]

28. Gregory, J.M.; Slaughter, J.C.; Duffus, S.H.; Smith, T.J.; LeStourgeon, L.M.; Jaser, S.S.; McCoy, A.B.; Luther, J.M.; Giovannetti, E.R.; Boeder, S.; et al. COVID-19 Severity Is Tripled in the Diabetes Community: A Prospective Analysis of the Pandemic's Impact in Type 1 and Type 2 Diabetes. Diabetes Care 2021, 44, 526-532. [CrossRef]

29. Vangoitsenhoven, R.; Martens, P.J.; van Nes, F.; Moyson, C.; Nobels, F.; Van Crombrugge, P.; Wierckx, K.; van Pottelbergh, I.; Van Huffel, L.; Gillard, P.; et al. No Evidence of Increased Hospitalization Rate for COVID-19 in Community-Dwelling Patients with Type 1 Diabetes. Diabetes Care 2020, 43, e118-e119. [CrossRef] [PubMed]

30. Ebekozien, O.; Agarwal, S.; Noor, N.; Albanese-O’Neill, A.; Wong, J.C.; Seeherunvong, T.; Sanchez, J.; DeSalvo, D.; Lyons, S.K.; Majidi, S.; et al. Inequities in Diabetic Ketoacidosis Among Patients With Type 1 Diabetes and COVID-19: Data From 52 US Clinical Centers. J. Clin. Endocrinol. Metab. 2021, 106, e1755-e1762. [CrossRef]

31. DiMeglio, L.A.; Albanese-O'Neill, A.; Muñoz, C.E.; Maahs, D.M. COVID-19 and Children With Diabetes-Updates, Unknowns, and Next Steps: First, Do No Extrapolation. Diabetes Care 2020, 43, 2631-2634. [CrossRef]

32. D'Annunzio, G.; Maffeis, C.; Cherubini, V.; Rabbone, I.; Scaramuzza, A.; Schiaffini, R.; Minuto, N.; Piccolo, G.; Maghnie, M. Caring for children and adolescents with type 1 diabetes mellitus: Italian Society for Pediatric Endocrinology and Diabetology (ISPED) statements during COVID-19 pandemia. Diabetes Res. Clin. Pract. 2020, 168, 108372. [CrossRef]

33. Rabbone, I.; Schiaffini, R.; Cherubini, V.; Maffeis, C.; Scaramuzza, A. Diabetes Study Group of the Italian Society for Pediatric Endocrinology and Diabetes. Has COVID-19 Delayed the Diagnosis and Worsened the Presentation of Type 1 Diabetes in Children? Diabetes Care 2020, 43, 2870-2872. [CrossRef] [PubMed]

34. Unsworth, R.; Wallace, S.; Oliver, N.S.; Yeung, S.; Kshirsagar, A.; Naidu, H.; Kwong, R.M.W.; Kumar, P.; Logan, K.M. New-Onset Type 1 Diabetes in Children During COVID-19: Multicenter Regional Findings in the U.K. Diabetes Care 2020, 43, e170-e171. [CrossRef]

35. Tittel, S.R.; Rosenbauer, J.; Kamrath, C.; Ziegler, J.; Reschke, F.; Hammersen, J.; Mönkemöller, K.; Pappa, A.; Kapellen, T.; Holl, R.W. DPV Initiative. Did the COVID-19 lockdown affect the incidence of pediatric type 1 diabetes in Germany? Diabetes Care 2020, 43, e172-e173. [CrossRef] 
36. Castaño, L.; Eisenbarth, G.S. Type-I diabetes: A chronic autoimmune disease of human, mouse, and rat. Annu Rev. Immunol. 1990, 8, 647-679. [CrossRef] [PubMed]

37. Lederman, M.M.; Schiffman, G.; Rodman, H.M. Pneumococcal immunization in adult diabetics. Diabetes 1981, 30, 119-121. [CrossRef]

38. Pozzilli, P.; Gale, E.A.; Visalli, N.; Baroni, M.; Crovari, P.; Frighi, V.; Cavallo, M.G.; Andreani, D. The immune response to influenza vaccination in diabetic patients. Diabetologia 1986, 29, 850-854. [CrossRef] [PubMed]

39. Valle, A.; Giamporcaro, G.M.; Scavini, M.; Stabilini, A.; Grogan, P.; Bianconi, E.; Sebastiani, G.; Masini, M.; Maugeri, N.; Porretti, L.; et al. Reduction of circulating neutrophils precedes and accompanies type 1 diabetes. Diabetes 2013, 62, 2072-2077. [CrossRef]

40. Jackson, M.H.; Collier, A.; Nicoll, J.J.; Muir, A.L.; Dawes, J.; Clarke, B.F.; Bell, D. Neutrophil count and activation in vascular disease. Scott. Med. J. 1992, 37, 41-43. [CrossRef]

41. Harsunen, M.H.; Puff, R.; D’Orlando, O.; Giannopoulou, E.; Lachmann, L.; Beyerlein, A.; von Meyer, A.; Ziegler, A.G. Reduced blood leukocyte and neutrophil numbers in the pathogenesis of type 1 diabetes. Horm. Metab. Res. 2013, 45, 467-470. [CrossRef] [PubMed]

42. Marhoffer, W.; Stein, M.; Schleinkofer, L.; Federlin, K. Evidence of ex vivo and in vitro impaired neutrophil oxidative burst and phagocytic capacity in type 1 diabetes mellitus. Diabetes Res. Clin. Pract. 1993, 19, 183-188. [CrossRef]

43. Delamaire, M.; Maugendre, D.; Moreno, M.; Le Goff, M.C.; Allannic, H.; Genetet, B. Exploration des différentes étapes du fonctionnement des polynucléaires neutrophiles chez les patients diabétiques [Exploration of the various steps of polymorphonuclear neutrophil function in diabetic patients. J. Mal. Vasc. 1995, 20, 107-112.

44. Merad, M.; Martin, J.C. Pathological inflammation in patients with COVID-19: A key role for monocytes and macrophages. Nat. Rev. Immunol. 2020, 20, 448. [CrossRef]

45. Wang, J.Z.; Zhang, R.Y.; Bai, J. An anti-oxidative therapy for ameliorating cardiac injuries of critically ill COVID-19-infected patients. Int. J. Cardiol. 2020, 312, 137-138. [CrossRef]

46. Barnes, B.J.; Adrover, J.M.; Baxter-Stoltzfus, A.; Borczuk, A.; Cools-Lartigue, J.; Crawford, J.M.; Daßler-Plenker, J.; Guerci, P.; Huynh, C.; Knight, J.S.; et al. Targeting potential drivers of COVID-19: Neutrophil extracellular traps. J. Exp. Med. 2020, 217, e20200652. [CrossRef] [PubMed]

47. Brinkmann, V.; Zychlinsky, A. Neutrophil extracellular traps: Is immunity the second function of chromatin? J. Cell Biol. 2012, 198, 773-783. [CrossRef] [PubMed]

48. Wang, Y.; Xiao, Y.; Zhong, L.; Ye, D.; Zhang, J.; Tu, Y.; Bornstein, S.R.; Zhou, Z.; Lam, K.S.; Xu, A. Increased neutrophil elastase and proteinase 3 and augmented NETosis are closely associated with $\beta$-cell autoimmunity in patients with type 1 diabetes. Diabetes 2014, 63, 4239-4248. [CrossRef] [PubMed]

49. Qin, J.; Fu, S.; Speake, C.; Greenbaum, C.J.; Odegard, J.M. NETosis-associated serum biomarkers are reduced in type 1 diabetes in association with neutrophil count. Clin. Exp. Immunol. 2016, 184, 318-322. [CrossRef]

50. Riyapa, D.; Buddhisa, S.; Korbsrisate, S.; Cuccui, J.; Wren, B.W.; Stevens, M.P.; Ato, M.; Lertmemongkolchai, G. Neutrophil extracellular traps exhibit antibacterial activity against burkholderia pseudomallei and are influenced by bacterial and host factors. Infect. Immun. 2012, 80, 3921-3929. [CrossRef]

51. Joshi, M.B.; Lad, A.; Prasad, A.S.; Balakrishnan, A.; Ramachandra, L.; Satyamoorthy, K. High glucose modulates IL-6 mediated immune homeostasis through impeding neutrophil extracellular trap formation. FEBS Lett. 2013, 587, 2241-2246. [CrossRef]

52. Li, Y.; Liu, Y.; Chu, C.Q. Th17 Cells in Type 1 Diabetes: Role in the Pathogenesis and Regulation by Gut Microbiome. Mediat. Inflamm. 2015, 2015, 638470. [CrossRef]

53. Ryba-Stanisławowska, M.; Skrzypkowska, M.; Myśliwska, J.; Myśliwiec, M. The serum IL-6 profile and Treg/Th17 peripheral cell populations in patients with type 1 diabetes. Mediat. Inflamm. 2013, 2013, 205284. [CrossRef]

54. Bradshaw, E.M.; Raddassi, K.; Elyaman, W.; Orban, T.; Gottlieb, P.A.; Kent, S.C.; Hafler, D.A. Monocytes from patients with type 1 diabetes spontaneously secrete proinflammatory cytokines inducing Th17 cells. J. Immunol. 2009, 183, 4432-4439. [CrossRef]

55. Kaizer, E.C.; Glaser, C.L.; Chaussabel, D.; Banchereau, J.; Pascual, V.; White, P.C. Gene expression in peripheral blood mononuclear cells from children with diabetes. J. Clin. Endocrinol. Metab. 2007, 92, 3705-3711. [CrossRef]

56. Menart-Houtermans, B.; Rütter, R.; Nowotny, B.; Rosenbauer, J.; Koliaki, C.; Kahl, S.; Simon, M.C.; Szendroedi, J.; Schloot, N.C.; Roden, M.; et al. Leukocyte profiles differ between type 1 and type 2 diabetes and are associated with metabolic phenotypes: Results from the German Diabetes Study (GDS). Diabetes Care 2014, 37, 2326-2333. [CrossRef] [PubMed]

57. Long, S.A.; Buckner, J.H. CD4+FOXP3+ T regulatory cells in human autoimmunity: More than a numbers game. J. Immunol. 2011, 187, 2061-2066. [CrossRef] [PubMed]

58. Kukreja, A.; Cost, G.; Marker, J.; Zhang, C.; Sun, Z.; Lin-Su, K.; Ten, S.; Sanz, M.; Exley, M.; Wilson, B.; et al. Multiple immuno-regulatory defects in type-1 diabetes. J. Clin. Investig. 2002, 109, 131-140. [CrossRef] [PubMed]

59. Wang, W.; Su, B.; Pang, L.; Qiao, L.; Feng, Y.; Ouyang, Y.; Guo, X.; Shi, H.; Wei, F.; Su, X.; et al. High-dimensional immune profiling by mass cytometry revealed immunosuppression and dysfunction of immunity in COVID-19 patients. Cell Mol. Immunol. 2020, 17, 650-652. [CrossRef]

60. Chen, Z.; Wherry, E. T cell responses in patients with COVID-19. Nat. Rev. Immunol. 2020, 20, 529-536. [CrossRef]

61. Lindley, S.; Dayan, C.M.; Bishop, A.; Roep, B.O.; Peakman, M. Tree TI. Defective suppressor function in CD4(+)CD25(+) T-cells from patients with type 1 diabetes. Diabetes 2005, 54, 92-99. [CrossRef] 
62. Zhou, Y.; Chi, J.; Lv, W.; Wang, Y. Obesity and diabetes as high-risk factors for severe coronavirus disease 2019 (Covid-19). Diabetes Metab. Res. Rev. 2021, 37, e3377. [CrossRef] [PubMed]

63. Chen, Y.; Gong, X.; Wang, L.; Guo, J. Effects of hypertension, diabetes and coronary heart disease on COVID-19 diseases severity: A systematic review and meta-analysis. medRxiv 2020. [CrossRef]

64. Pambianco, G.; Costacou, T.; Orchard, T.J. The prediction of major outcomes of type 1 diabetes: A 12-year prospective evaluation of three separate definitions of the metabolic syndrome and their components and estimated glucose disposal rate: The Pittsburgh Epidemiology of Diabetes Complications Study experience. Diabetes Care 2007, 30, 1248-1254. [PubMed]

65. Priya, G.; Kalra, S. A Review of Insulin Resistance in Type 1 Diabetes: Is There a Place for Adjunctive Metformin? Diabetes Ther. 2018, 9, 349-361. [CrossRef] [PubMed]

66. Kaul, K.; Apostolopoulou, M.; Roden, M. Insulin resistance in type 1 diabetes mellitus. Metabolism 2015, 64, 1629-1639. [CrossRef] [PubMed]

67. Nishida, K.; Otsu, K. Inflammation and metabolic cardiomyopathy. Cardiovasc. Res. 2017, 113, 389-398. [CrossRef]

68. Pan, X.; Kaminga, A.C.; Wen, S.W.; Acheampong, K.; Liu, A. Omentin-1 in diabetes mellitus: A systematic review and metaanalysis. PLoS ONE 2019, 14, e0226292. [CrossRef]

69. Luc, K.; Schramm-Luc, A.; Guzik, T.J.; Mikolajczyk, T.P. Oxidative stress and inflammatory markers in prediabetes and diabetes. J. Physiol. Pharmacol. 2019, 70. [CrossRef]

70. Domingueti, C.P.; Dusse, L.M.; Carvalho, M.D.; de Sousa, L.P.; Gomes, K.B.; Fernandes, A.P. Diabetes mellitus: The linkage between oxidative stress, inflammation, hypercoagulability and vascular complications. J. Diabetes Complicat. 2016, 30, 738-745. [CrossRef]

71. Gouda, W.; Mageed, L.; Abd El Dayem, S.M.; Ashour, E.; Afify, M. Evaluation of pro-inflammatory and anti-inflammatory cytokines in type 1 diabetes mellitus. Bull. Natl. Res. Cent. 2018, 42, 14. [CrossRef]

72. Dogan, Y.; Akarsu, S.; Ustundag, B.; Yilmaz, E.; Gurgoze, M.K. Serum IL-1beta, IL-2, and IL-6 in insulin-dependent diabetic children. Mediat. Inflamm. 2006, 2006, 59206. [CrossRef]

73. Talaat, I.M.; Nasr, A.; Alsulaimani, A.A.; Alghamdi, H.; Alswat, K.A.; Almalki, D.M.; Abushouk, A.; Saleh, A.M.; Allam, G. Association between type 1, type 2 cytokines, diabetic autoantibodies and 25-hydroxyvitamin D in children with type 1 diabetes. J. Endocrinol. Investig. 2016, 39, 1425-1434. [CrossRef]

74. Ururahy, M.A.; Loureiro, M.B.; Freire-Neto, F.P.; de Souza, K.S.; Zuhl, I.; Brandão-Neto, J.; Hirata, R.D.; Doi, S.Q.; Arrais, R.F.; Hirata, M.H. Almeida Md, de Rezende AA. Increased TLR2 expression in patients with type 1 diabetes: Evidenced risk of microalbuminuria. Pediatr. Diabetes 2012, 13, 147-154. [CrossRef]

75. Hunt, K.J.; Baker, N.L.; Cleary, P.A.; Klein, R.; Virella, G.; Lopes-Virella, M.F. DCCT/EDIC Group of Investigators. Longitudinal Association Between Endothelial Dysfunction, Inflammation, and Clotting Biomarkers with Subclinical Atherosclerosis in Type 1 Diabetes: An Evaluation of the DCCT/EDIC Cohort. Diabetes Care 2015, 38, 1281-1289. [CrossRef]

76. Devaraj, S.; Glaser, N.; Griffen, S.; Wang-Polagruto, J.; Miguelino, E.; Jialal, I. Increased monocytic activity and biomarkers of inflammation in patients with type 1 diabetes. Diabetes 2006, 55, 774-779. [CrossRef] [PubMed]

77. Kulseng, B.; Skjåk-Braek, G.; Følling, I.; Espevik, T. TNF production from peripheral blood mononuclear cells in diabetic patients after stimulation with alginate and lipopolysaccharide. Scand. J. Immunol. 1996, 43, 335-340. [CrossRef] [PubMed]

78. Hussain, M.J.; Maher, J.; Warnock, T.; Vats, A.; Peakman, M.; Vergani, D. Cytokine overproduction in healthy first degree relatives of patients with IDDM. Diabetologia 1998, 41, 343-349. [CrossRef]

79. Schram, M.T.; Chaturvedi, N.; Schalkwijk, C.; Giorgino, F.; Ebeling, P.; Fuller, J.H.; Stehouwer, C.D. EURODIAB Prospective Complications Study. Vascular risk factors and markers of endothelial function as determinants of inflammatory markers in type 1 diabetes: The EURODIAB Prospective Complications Study. Diabetes Care 2003, 26, 2165-2173. [CrossRef] [PubMed]

80. Wu, C.; Chen, X.; Cai, Y.; Xia, J.; Zhou, X.; Xu, S.; Huang, H.; Zhang, L.; Zhou, X.; Du, C.; et al. Risk Factors Associated With Acute Respiratory Distress Syndrome and Death in Patients With Coronavirus Disease 2019 Pneumonia in Wuhan, China. JAMA Intern. Med. 2020, 180, 934-943. [CrossRef]

81. Mehta, P.; McAuley, D.F.; Brown, M.; Sanchez, E.; Tattersall, R.S.; Manson, J.J. COVID-19: Consider cytokine storm syndromes and immunosuppression. Lancet 2020, 395, 1033-1034. [CrossRef]

82. Brownlee, M. Biochemistry and molecular cell biology of diabetic complications. Nature 2001, 414, 813-820. [CrossRef]

83. Lambadiari, V.; Kousathana, F.; Raptis, A.; Katogiannis, K.; Kokkinos, A.; Ikonomidis, I. Pre-Existing Cytokine and NLRP3 Inflammasome Activation and Increased Vascular Permeability in Diabetes: A Possible Fatal Link with Worst COVID-19 Infection Outcomes? Front. Immunol. 2020, 11, 557235. [CrossRef] [PubMed]

84. Ratajczak, M.Z.; Kucia, M. SARS-CoV-2 infection and overactivation of Nlrp3 inflammasome as a trigger of cytokine "storm" and risk factor for damage of hematopoietic stemcells. Leukemia 2020, 34, 1726-1729. [CrossRef]

85. Delgado-Roche, L.; Mesta, F. Oxidative Stress as Key Player in Severe Acute Respiratory Syndrome Coronavirus (SARS-CoV) Infection. Arch. Med. Res. 2020, 51, 384-387. [CrossRef]

86. Pizzino, G.; Irrera, N.; Cucinotta, M.; Pallio, G.; Mannino, F.; Arcoraci, V.; Squadrito, F.; Altavilla, D.; Bitto, A. Oxidative Stress: Harms and Benefits for Human Health. Oxid. Med. Cell Longev. 2017, 2017, 8416763. [CrossRef] [PubMed]

87. Betteridge, D.J. What is oxidative stress? Metabolism 2000, 49, 3-8. [CrossRef]

88. Stadler, K. Oxidative stress in diabetes. Adv. Exp. Med. Biol. 2012, 771, 272-287. [PubMed] 
89. Nishikawa, T.; Edelstein, D.; Du, X.L.; Yamagishi, S.; Matsumura, T.; Kaneda, Y.; Yorek, M.A.; Beebe, D.; Oates, P.J.; Hammes, H.P.; et al. Normalizing mitochondrial superoxide production blocks three pathways of hyperglycaemic damage. Nature 2000, 404, 787-790. [CrossRef] [PubMed]

90. Fatima, N.; Faisal, S.M.; Zubair, S.; Ajmal, M.; Siddiqui, S.S.; Moin, S.; Owais, M. Role of Pro-Inflammatory Cytokines and Biochemical Markers in the Pathogenesis of Type 1 Diabetes: Correlation with Age and Glycemic Condition in Diabetic Human Subjects. PLoS ONE 2016, 11, e0161548. [CrossRef]

91. Firoozrai, M.; Nourbakhsh, M.; Razzaghy-Azar, M. Erythrocyte susceptibility to oxidative stress and antioxidant status in patients with type 1 diabetes. Diabetes Res. Clin. Pract. 2007, 77, 427-432. [CrossRef] [PubMed]

92. Gleisner, A.; Martinez, L.; Pino, R.; Rojas, I.G.; Martinez, A.; Asenjo, S.; Rudolph, M.I. Oxidative stress markers in plasma and urine of prepubertal patients with type 1 diabetes mellitus. J. Pediatr. Endocrinol. Metab. 2006, 19, 995-1000. [CrossRef]

93. Ziobro, A.; Duchnowicz, P.; Mulik, A.; Koter-Michalak, M.; Broncel, M. Oxidative damages in erythrocytes of patients with metabolic syndrome. Mol. Cell Biochem. 2013, 378, 267-273. [CrossRef] [PubMed]

94. Cacciatore, I.; Cornacchia, C.; Pinnen, F.; Mollica, A.; Di Stefano, A. Prodrug Approach for Increasing Cellular Glutathione Levels. Molecules 2010, 15, 1242-1264. [CrossRef]

95. Elhadd, T.A.; Khan, F.; Kirk, G.; McLaren, M.; Newton, R.W.; Greene, S.A. Influence of puberty on endothelial dysfunction and oxidative stress in young patients with type 1 diabetes. Diabetes Care 1998, 21, 1990-1996. [CrossRef] [PubMed]

96. Ruiz, C.; Algeria, A.; Barbera, R.; Farre, R.; Lagarda, M.J. Lipid peroxidation and antioxidant enzyme activities in patients with type 1 diabetes mellitus. Scand. J. Clin. Lab. Investig. 1999, 59, 99-106. [CrossRef]

97. Grunnet, L.G.; Mandrup-Poulsen, T. Cytokines and type 1 diabetes: A numbers game. Diabetes 2011, 60, 697-699. [CrossRef] [PubMed]

98. Rincón, J.; Correia, D.; Arcaya, J.L.; Finol, E.; Fernández, A.; Pérez, M.; Yaguas, K.; Talavera, E.; Chávez, M.; Summer, R.; et al. Role of Angiotensin II type 1 receptor on renal NAD(P)H oxidase, oxidative stress and inflammation in nitric oxide inhibition induced-hypertension. Life Sci. 2015, 124, 81-90. [CrossRef] [PubMed]

99. Beltrán-García, J.; Osca-Verdegal, R.; Pallardó, F.V.; Ferreres, J.; Rodríguez, M.; Mulet, S.; Sanchis-Gomar, F.; Carbonell, N.; García-Giménez, J.L. Oxidative Stress and Inflammation in COVID-19-Associated Sepsis: The Potential Role of Anti-Oxidant Therapy in Avoiding Disease Progression. Antioxidants 2020, 9, 936. [CrossRef] [PubMed]

100. Cecchini, R.; Cecchini, A.L. SARS-CoV-2 infection pathogenesis is related to oxidative stress as a response to aggression. Med. Hypotheses 2020, 143, 110102. [CrossRef]

101. Nanduri, J.; Yuan, G.; Kumar, G.K.; Semenza, G.L.; Prabhakar, N.R. Transcriptional responses to intermittent hypoxia. Respir. Physiol. Neurobiol. 2008, 164, 277-281. [CrossRef]

102. Cavezzi, A.; Troiani, E.; Corrao, S. COVID-19: Hemoglobin, iron, and hypoxia beyond inflammation. A narrative review. Clin. Pract. 2020, 10, 1271. [CrossRef]

103. Schechter, A.N.; Gladwin, M.T. Hemoglobin and the paracrine and endocrine functions of nitric oxide. N. Engl. J. Med. 2003, 348, 1483-1485. [CrossRef]

104. Furchgott, R.F.; Zawadzki, J.V. The obligatory role of endothelial cells in the relaxation of arterial smooth muscle by acetylcholine. Nature 1980, 288, 373-376. [CrossRef]

105. Deanfield, J.E.; Halcox, J.P.; Rabelink, T.J. Endothelial function and dysfunction: Testing and clinical relevance. Circulation 2007, 115, 1285-1295. [CrossRef]

106. Van Teeffelen, J.W.; Brands, J.; Stroes, E.S.; Vink, H. Endothelial glycocalyx: Sweet shield of blood vessels. Trends Cardiovasc. Med. 2007, 17, 101-105. [CrossRef] [PubMed]

107. Cé, G.V.; Rohde, L.E.; da Silva, A.M.; Puñales, M.K.; de Castro, A.C.; Bertoluci, M.C. Endothelial dysfunction is related to poor glycemic control in adolescents with type 1 diabetes under 5 years of disease: Evidence of metabolic memory. J. Clin. Endocrinol. Metab. 2011, 96, 1493-1499. [CrossRef] [PubMed]

108. Järvisalo, M.J.; Raitakari, M.; Toikka, J.O.; Putto-Laurila, A.; Rontu, R.; Laine, S.; Lehtimäki, T.; Rönnemaa, T.; Viikari, J.; Raitakari, O.T. Endothelial dysfunction and increased arterial intima-media thickness in children with type 1 diabetes. Circulation 2004, 109, 1750-1755. [CrossRef]

109. Machnica, L.; Deja, G.; Polanska, J.; Czupryniak, L.; Szymanska-Garbacz, E.; Loba, J.; Jarosz-Chobot, P. Blood pressure disturbances and endothelial dysfunction markers in children and adolescents with type 1 diabetes. Atherosclerosis 2014, 237, 129-134. [CrossRef] [PubMed]

110. Perrin, R.M.; Harper, S.J.; Bates, D.O. A role for the endothelial glycocalyx in regulating microvascular permeability in diabetes mellitus. Cell Biochem. Biophys. 2007, 49, 65-72. [CrossRef]

111. Onat, D.; Brillon, D.; Colombo, P.C.; Schmidt, A.M. Human vascular endothelial cells: A model system for studying vascular inflammation in diabetes and atherosclerosis. Curr. Diab. Rep. 2011, 11, 193-202. [CrossRef]

112. Lemkes, B.A.; Nieuwdorp, M.; Hoekstra, J.B.; Holleman, F. The glycocalyx and cardiovascular disease in diabetes: Should we judge the endothelium by its cover? Diabetes Technol. Ther. 2012, 14 (Suppl. 1), S3-S10. [CrossRef]

113. Nieuwdorp, M.; van Haeften, T.W.; Gouverneur, M.C.; Mooij, H.L.; van Lieshout, M.H.; Levi, M.; Meijers, J.C.; Holleman, F.; Hoekstra, J.B.; Vink, H.; et al. Loss of endothelial glycocalyx during acute hyperglycemia coincides with endothelial dysfunction and coagulation activation in vivo. Diabetes 2006, 55, 480-486. [CrossRef] 
114. Giannini, C.; Mohn, A.; Chiarelli, F.; Kelnar, C.J. Macrovascular angiopathy in children and adolescents with type 1 diabetes. Diabetes Metab. Res. Rev. 2011, 27, 436-460. [CrossRef]

115. Kessler, L.; Wiesel, M.L.; Attali, P.; Mossard, J.M.; Cazenave, J.P.; Pinget, M. Von Willebrand factor in diabetic angiopathy. Diabetes Metab. 1998, 24, 327-336.

116. Margetic, S. Inflammation and haemostasis. Biochem. Med. 2012, 22, 49-62. [CrossRef]

117. Oliveira, S.F.; Guillausseau, P.J. Diabetes, advanced glycation end products and vascular disease. Vasc. Med. $1998,3,131-137$.

118. Yamagishi, S.; Matsui, T. Advanced glycation end products, oxidative stress and diabetic nephropathy. Oxid. Med. Cell Longev. 2010, 3, 101-108. [CrossRef] [PubMed]

119. Sena, C.M.; Pereira, A.M.; Seiça, R. Endothelial dysfunction-A major mediator of diabetic vascular disease. Biochem. Biophys. Acta 2013, 1832, 2216-2231. [CrossRef] [PubMed]

120. Hamming, I.; Timens, W.; Bulthuis, M.; Lely, A.; Navis, G.; van Goor, H. Tissue distribution of ACE2 protein, the functional receptor for SARS coronavirus. A first step in understanding SARS pathogenesis. J. Pathol. 2004, 203, 631-637. [CrossRef]

121. Chen, L.; Li, X.; Chen, M.; Feng, Y.; Xiong, C. The ACE2 expression in human heart indicates new potential mechanism of heart injury among patients infected with SARS-CoV-2. Cardiovasc. Res. 2020, 116, 1097-1100. [CrossRef] [PubMed]

122. Oudit, G.Y.; Kassiri, Z.; Jiang, C.; Liu, P.P.; Poutanen, S.M.; Penninger, J.M.; Butany, J. SARS-coronavirus modulation of myocardial ACE2 expression and inflammation in patients with SARS. Eur. J. Clin. Investig. 2009, 39, 618-625. [CrossRef]

123. Wassmann, S.; Stumpf, M.; Strehlow, K.; Schmid, A.; Schieffer, B.; Böhm, M.; Nickenig, G. Interleukin-6 induces oxidative stress and endothelial dysfunction by overexpression of the angiotensin II type 1 receptor. Circ. Res. 2004, 94, 534-541. [CrossRef]

124. Szotowski, B.; Antoniak, S.; Poller, W.; Schultheiss, H.P.; Rauch, U. Procoagulant soluble tissue factor is released fromendothelial cells in response to inflammatory cytokines. Circ. Res. 2005, 96, 1233-1239. [CrossRef]

125. Chelazzi, C.; Villa, G.; Mancinelli, P.; De Gaudio, A.R.; Adembri, C. Glycocalyx and sepsis-induced alterations in vascular permeability. Crit. Care 2015, 19, 26. [CrossRef] [PubMed]

126. He, L.; Ding, Y.; Zhang, Q.; Che, X.; He, Y.; Shen, H.; Wang, H.; Li, Z.; Zhao, L.; Geng, J.; et al. Expression of elevated levels of pro-inflammatory cytokines in SARS-CoV-infected ACE2+ cells in SARS patients: Relation to the acute lung injury and pathogenesis of SARS. J. Pathol. 2006, 210, 288-297. [CrossRef]

127. Varga, Z.; Flammer, A.J.; Steiger, P.; Haberecker, M.; Andermatt, R.; Zinkernagel, A.S.; Mehra, M.R.; Schuepbach, R.A.; Ruschitzka, F.; Moch, H. Endothelial cell infection and endotheliitis in COVID-19. Lancet 2020, 395, 1417-1418. [CrossRef]

128. Su, H.; Yang, M.; Wan, C.; Yi, L.X.; Tang, F.; Zhu, H.Y.; Yi, F.; Yang, H.C.; Fogo, A.B.; Nie, X.; et al. Renal histopathological analysis of 26 postmortem findings of patients with COVID-19 in China. Kidney Int. 2020, 98, 219-227. [CrossRef]

129. Copin, M.C.; Parmentier, E.; Duburcq, T.; Poissy, J.; Mathieu, D.; Lille COVID-19 ICU and Anatomopathology Group. Time to consider histologic pattern of lung injury to treat critically ill patients with COVID-19 infection. Intensive Care Med. 2020, 46, 1124-1126. [CrossRef]

130. Sobczak, A.I.S.; Stewart, A.J. Coagulatory Defects in Type-1 and Type-2 Diabetes. Int. J. Mol. Sci. 2019, 20, 6345. [CrossRef]

131. Galajda, P.; Martinka, E.; Mokan, M.; Kubisz, P. Endothelial markers in diabetes mellitus. Thromb. Res. 1997, 85, 63-65. [CrossRef]

132. Singh, A.; Boden, G.; Homko, C.; Gunawardana, J.; Rao, A.K. Whole-blood tissue factor procoagulant activity is elevated in type 1 diabetes: E_ects of hyperglycemia and hyperinsulinemia. Diabetes Care 2012, 35, 1322-1327. [CrossRef]

133. Kim, H.K.; Kim, J.E.; Park, S.H.; Kim, Y.I.; Nam-Goong, I.S.; Kim, E.S. High coagulation factor levels and low protein C levels contribute to enhanced thrombin generation in patients with diabetes who do not have macrovascular complications. J. Diabetes Complicat. 2014, 28, 365-369. [CrossRef]

134. Klein, R.L.; Hunter, S.J.; Jenkins, A.J.; Zheng, D.; Semler, A.J.; Clore, J.; Garvey, W.T.; Dcct/Ecic Study, G. Fibrinogen is a marker for nephropathy and peripheral vascular disease in type 1 diabetes: Studies of plasma fibrinogen and fibrinogen gene polymorphism in the DCCT/EDIC cohort. Diabetes Care 2003, 26, 1439-1448. [CrossRef] [PubMed]

135. Ajjan, R.A.; Gamlen, T.; Standeven, K.F.; Mughal, S.; Hess, K.; Smith, K.A.; Dunn, E.J.; Anwar, M.M.; Rabbani, N.; Thornalley, P.J.; et al. Diabetes is associated with posttranslational modifications in plasminogen resulting in reduced plasmin generation and enzyme-specific activity. Blood 2013, 122, 134-142. [CrossRef]

136. Reverter, J.L.; Reverter, J.C.; Tassies, D.; Rius, F.; Monteagudo, J.; Rubies-Prat, J.; Escolar, G.; Ordinas, A.; Sanmarti, A. Thrombomodulin and induced tissue factor expression on monocytes as markers of diabetic microangiopathy: Aprospective study on hemostasis and lipoproteins in insulin-dependent diabetes mellitus. Am. J. Hematol. 1997, 56, 93-99. [CrossRef]

137. Yasuma, T.; Yano, Y.; D’Alessandro-Gabazza, C.N.; Toda, M.; Gil-Bernabe, P.; Kobayashi, T.; Nishihama, K.; Hinneh, J.A.; Mifuji-Moroka, R.; Roeen, Z.; et al. Amelioration of Diabetes by Protein, S. Diabetes 2016, 65, 1940-1951. [CrossRef] [PubMed]

138. Jacobson, R.; Mignemi, N.; Rose, K.; O’Rear, L.; Sarilla, S.; Hamm, H.E.; Barnett, J.V.; Verhamme, I.M.; Schoenecker, J. The hyperglycemic byproduct methylglyoxal impairs anticoagulant activity through covalent adduction of antithrombin III. Thromb. Res. 2014, 134, 1350-1357. [CrossRef]

139. Sherif, E.M.; Elbarbary, N.S.; Abd Al Aziz, M.M.; Mohamed, S.F. Plasma thrombin-activatable fibrinolysis inhibitor levels in children and adolescents with type 1 diabetes mellitus: Possible relation to diabetic microvascular complications. Blood Coagul. Fibrinolysis 2014, 25, 451-457. [CrossRef] [PubMed]

140. Ceriello, A.; Giugliano, D.; Quatraro, A.; Stante, A.; Russo, P.; Torella, R. Increased alpha 2-macroglobulin in diabetes: A hyperglycemia related phenomenon associated with reduced antithrombin III activity. Acta Diabetol. Lat. 1989, 26, 147-154. [CrossRef] 
141. Morel, O.; Jesel, L.; Abbas, M.; Morel, N. Prothrombotic changes in diabetes mellitus. Semin. Thromb. Hemost. 2013, 39 , 477-488.

142. Winocour, P.D.; Watala, C.; Perry, D.W.; Kinlough-Rathbone, R.L. Decreased platelet membrane fluidity due to glycation or acetylation of membrane proteins. Thromb. Haemost. 1992, 68, 577-582. [CrossRef]

143. Assert, R.; Scherk, G.; Bumbure, A.; Pirags, V.; Schatz, H.; Pfeier, A.F. Regulation of protein kinase C byshort term hyperglycaemia in human platelets in vivo and in vitro. Diabetologia 2001, 44, 188-195. [CrossRef]

144. Schaeer, G.; Wascher, T.C.; Kostner, G.M.; Graier, W.F. Alterations in platelet Ca2+ signalling in diabetic patients is due to increased formation of superoxide anions and reduced nitric oxide production. Diabetologia 1999, 42, 167-176. [CrossRef]

145. Zhou, F.; Yu, T.; Du, R.; Fan, G.; Liu, Y.; Liu, Z.; Xiang, J.; Wang, Y.; Song, B.; Gu, X.; et al. Clinical course and risk factors for mortality of adult inpatients with COVID-19 in Wuhan, China: A retrospective cohort study. Lancet 2020, 395, 1054-1062. [CrossRef]

146. Cui, S.; Chen, S.; Li, X.; Liu, S.; Wang, F. Prevalence of venous thromboembolism in patients with severe novel coronavirus pneumonia. J. Thromb. Haemost. 2020, 18, 1421-1424. [CrossRef]

147. Klok, F.A.; Kruip, M.J.H.A.; van der Meer, N.J.M.; Arbous, M.S.; Gommers, D.A.M.P.J.; Kant, K.M.; Kaptein, F.H.J.; van Paassen, J.; Stals, M.A.M.; Huisman, M.V.; et al. Incidence of thrombotic complications in critically ill ICU patients with COVID-19. Thromb. Res. 2020, 191, 145-147. [CrossRef] [PubMed]

148. Tang, N.; Li, D.; Wang, X.; Sun, Z. Abnormal coagulation parameters are associated with poor prognosis in patients with novel coronavirus pneumonia. J. Thromb. Haemost. 2020, 18, 844-847. [CrossRef] [PubMed]

149. Magro, C.; Mulvey, J.J.; Berlin, D.; Nuovo, G.; Salvatore, S.; Harp, J.; Baxter-Stoltzfus, A.; Laurence, J. Complement associated microvascular injury and thrombosis in the pathogenesis of severe COVID-19 infection: A report of five cases. Transl. Res. 2020, 220, 1-13. [CrossRef]

150. Tikellis, C.; Thomas, M.C. Angiotensin-Converting Enzyme 2 (ACE2) Is a Key Modulator of the Renin Angiotensin System in Health and Disease. Int. J. Pept. 2012, 2012, 1-8. [CrossRef] [PubMed]

151. Li, W.; Moore, M.J.; Vasilieva, N.; Sui, J.; Wong, S.K.; Berne, M.A.; Somasundaran, M.; Sullivan, J.L.; Luzuriaga, K.; Greenough, T.C.; et al. Angiotensin-converting enzyme 2 is a functional receptor for the SARS coronavirus. Nature 2003, 426, 450-454. [CrossRef]

152. Roks, A.J.; van Geel, P.P.; Pinto, Y.M.; Buikema, H.; Henning, R.H.; de Zeeuw, D.; van Gilst, W.H. Angiotensin-(1-7) is a modulator of the human renin- angiotensin system. Hypertension 1999, 34, 296-301. [CrossRef] [PubMed]

153. Tom, B.; de Vries, R.; Saxena, P.R.; Danser, A.H. Bradykinin potentiation by angiotensin-(1-7) and ACE inhibitors correlates with ACE C- and N- domain blockade. Hypertension 2001, 38, 95-99. [CrossRef] [PubMed]

154. Pober, J.S.; Sessa, W.C. Evolving functions of endothelial cells in inflammation. Nat. Rev. Immunol. 2007, 7, 803-815. [CrossRef]

155. Zou, Z.; Yan, Y.; Shu, Y.; Gao, R.; Sun, Y.; Li, X.; Ju, X.; Liang, Z.; Liu, Q.; Zhao, Y.; et al. Angiotensin-converting enzyme 2 protects from lethal avian influenza A H5N1 infections. Nat. Commun. 2014, 5, 3594. [CrossRef] [PubMed]

156. Bornstein, S.R.; Rubino, F.; Khunti, K.; Mingrone, G.; Hopkins, D.; Birkenfeld, A.L.; Boehm, B.; Amiel, S.; Holt, R.I.; Skyler, J.S.; et al. Practical recommendations for the management of diabetes in patients with COVID-19. Lancet Diabetes Endocrinol. 2020, 8, 546-550. [CrossRef]

157. Bindom, S.M.; Lazartigues, E. The sweeter side of ACE2: Physiological evidence for a role in diabetes. Mol. Cell Endocrinol. 2009, 302, 193-202. [CrossRef] [PubMed]

158. Roca-Ho, H.; Riera, M.; Palau, V.; Pascual, J.; Soler, M.J. Characterization of ACE and ACE2 Expression within Different Organs of the NOD Mouse. Int. J. Mol. Sci. 2017, 18, 563. [CrossRef]

159. Monteil, V.; Kwon, H.; Prado, P.; Hagelkrüys, A.; Wimmer, R.A.; Stahl, M.; Leopoldi, A.; Garreta, E.; Hurtado Del Pozo, C.; Prosper, F; , et al. Inhibition of SARS-CoV-2 Infections in Engineered Human Tissues Using Clinical-Grade Soluble Human ACE2. Cell 2020, 181, 905-913. [CrossRef]

160. Müller, J.A.; Groß, R.; Conzelmann, C.; Krüger, J.; Merle, U.; Steinhart, J.; Weil, T.; Koepke, L.; Bozzo, C.P.; Read, C.; et al. SARS-CoV-2 infects and replicates in cells of the human endocrine and exocrine pancreas. Nat. Metab. 2021, 3, 149-165. [CrossRef]

161. Yang, L.; Han, Y.; Nilsson-Payant, B.E.; Gupta, V.; Wang, P.; Duan, X.; Tang, X.; Zhu, J.; Zhao, Z.; Jaffré, F.; et al. A Human Pluripotent Stem Cell-based Platform to Study SARS-CoV-2 Tropism and Model Virus Infection in Human Cells and Organoids. Cell Stem Cell. 2020, 27, 125-136. [CrossRef]

162. Yu, M.G.; Keenan, H.A.; Shah, H.S.; Frodsham, S.G.; Pober, D.; He, Z.; Wolfson, E.A.; D’Eton, S.; Tinsley, L.J.; Bonner-Weir, S.; et al. Residual beta cell function and monogenic variants in long-duration type 1 diabetes patients. J. Clin. Investig. 2019, 129, 3252-3263. [CrossRef]

163. Li, J.; Wang, X.; Chen, J.; Zuo, X.; Zhang, H.; Deng, A. COVID-19 infection may cause ketosis and ketoacidosis. Diabetes Obes. Metab. 2020, 22, 1935-1941. [CrossRef] [PubMed]

164. Kamrath, C.; Mönkemöller, K.; Biester, T.; Rohrer, T.R.; Warncke, K.; Hammersen, J.; Holl, R.W. Ketoacidosis in Children and Adolescents with Newly Diagnosed Type 1 Diabetes During the COVID-19 Pandemic in Germany. JAMA 2020, 324, 801-804. [CrossRef] [PubMed]

165. Hollstein, T.; Schulte, D.M.; Schulz, J.; Glück, A.; Ziegler, A.G.; Bonifacio, E.; Wendorff, M.; Franke, A.; Schreiber, S.; Bornstein, S.R.; et al. Autoantibody-negative insulin-dependent diabetes mellitus after SARS-CoV-2 infection: A case report. Nat. Metab. 2020, 2, 1021-1024. [CrossRef] 
166. Potier, L.; Julla, J.B.; Roussel, R.; Boudou, P.; Gauthier, D.C.; Ketfi, C.; Gautier, J.F. COVID-19 symptoms masking inaugural ketoacidosis of type 1 diabetes. Diabetes Metab. 2021, 47, 101162. [CrossRef] [PubMed]

167. Yang, J.K.; Lin, S.S.; Ji, X.J.; Guo, L.M. Binding of SARS coronavirus to its receptor damages islets and causes acute diabetes. Acta Diabetol. 2010, 47, 193-199. [CrossRef] [PubMed] 